\title{
فاعلية برنامهج تدريبي لتسعير منتجات الملابس الجاهزة
}

\author{
د. خالد مصطفى عابد \\ أ. أد ماجدة محمد ماضي \\ مدرس بقسم الملابس والنسيج \\ أستاذ تصنيع وانتاج الملابس بقسم الملابس هليس \\ كلية الاقتصاد المنزلي جامعة حلوان

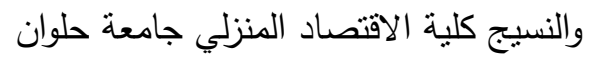

\author{
محمد مسعد محمد قطب \\ بكالوريوس الاقتصاد المنزلي قسم الملابس

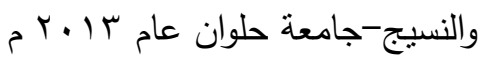

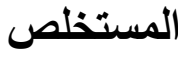

يهدف البحث الي تصميم وتجريب برنامج تدريبي لتسعير الملابس الجاهزة من خلال حساب التكاليف لخريجين الكليات المتخصصة والعاملين بالمشروعات الصغيرة وذللك للمساهمة في رفع كفاءة الخريج بما يؤهله لمستقبل مهني ناجح، قياس فاعلية البرنامج التدريبي في تتمية باتية

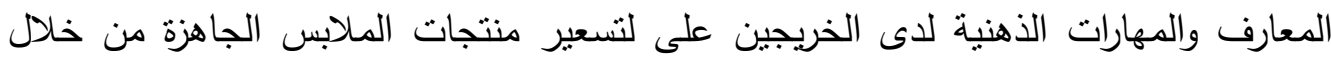
حساب التكاليف، و توصل البحث الي توجد فروق دالة إحصائيا بين منوسطي درجات

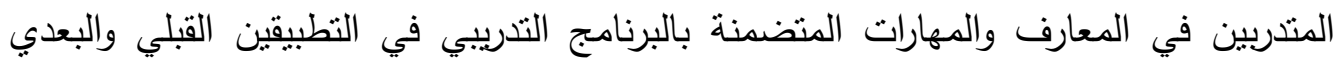
لصالح التطبيق البعدي و توجد فروق دالة إحصائيا بين منوسطي درجات المتدربين في

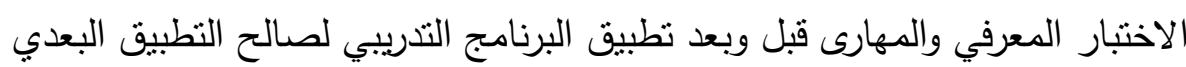

\section{Sourcing Merchandiser at Benetton Group S.R.L}

\section{Abstract}

The aim of the research is to design and test a training program for the pricing of ready-made garments through the costing of graduates of specialized colleges and small- project workers to contribute to the graduation of the graduates in order to qualify for a successful career.

The research found that there are statistically significant differences between the average trainees in the knowledge and skills included in the training program in the tribal and remote applications in favour of the post application. There are statistically significant differences between the average trainees in the cognitive and skill tests before and after the application of the training program 


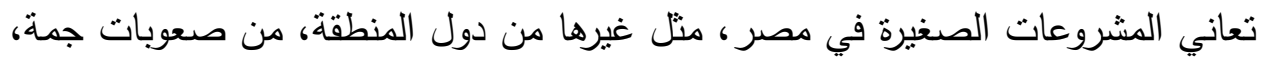

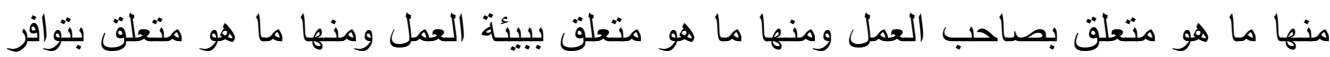

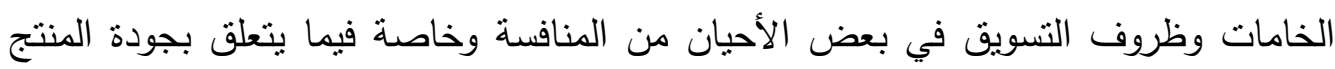

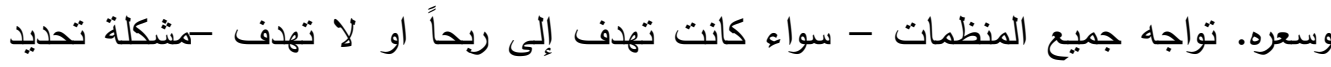

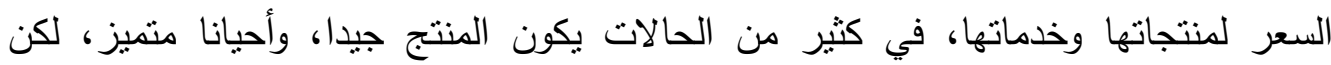

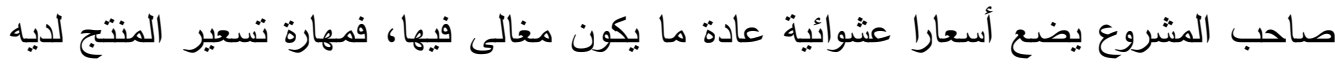

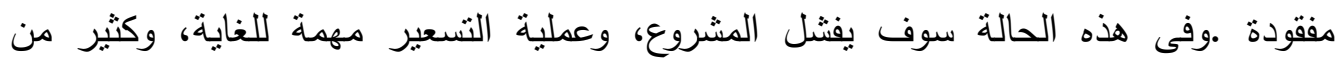

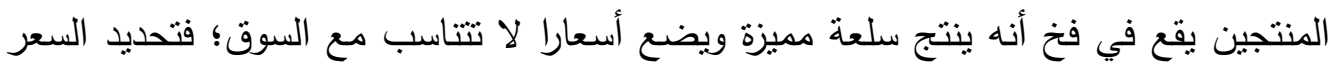

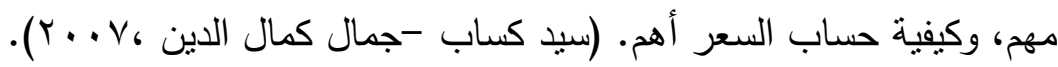

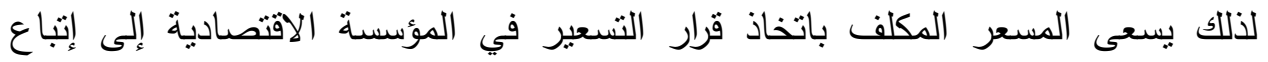

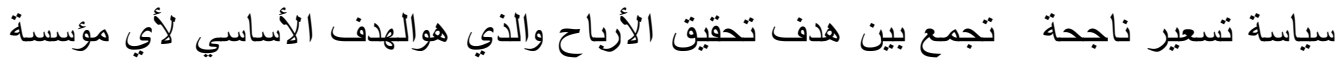

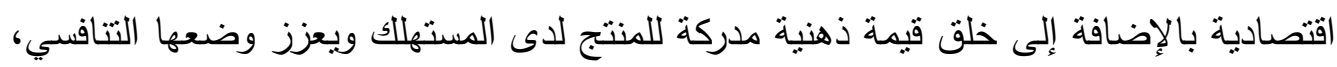

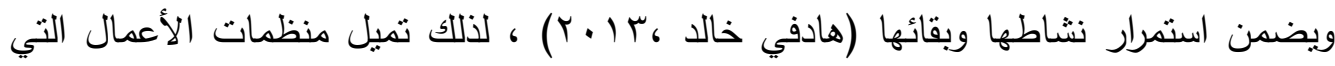

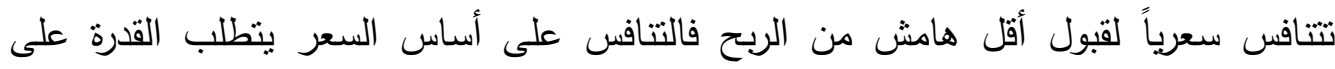

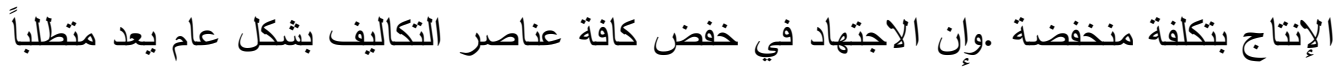

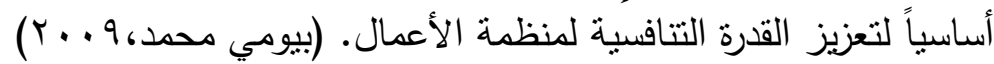
ومن المفترض أن يكون هامش الربح معقولا وعادلا، حيث ترضى الأبـى المنشأة بالربح العادل

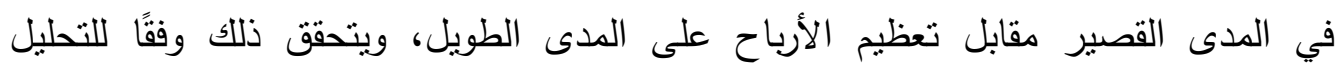
الاقتصادي بتعظيم الإيرادات أو تدنية التكاليف باختيار المزيج الميج الأمنل لعناصر الإنتاج، أوالمزيج

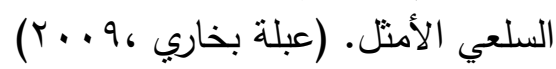
كما ان للبرامج المتخصصة أهمية خاصة في علئ عملية حساب تكاليف المنتج والقرارات

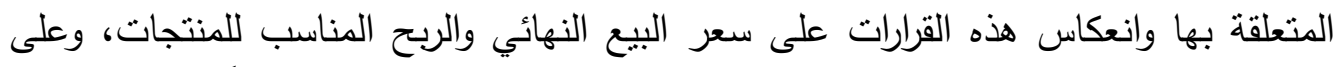

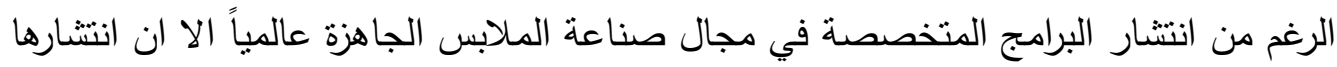

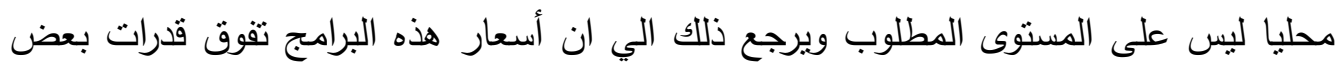

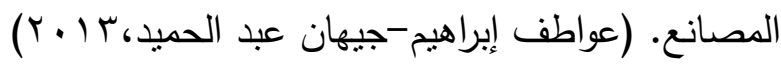

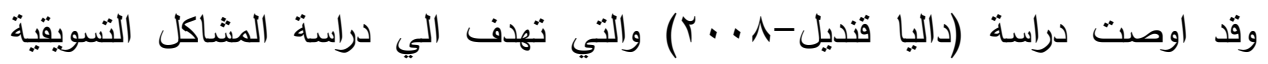

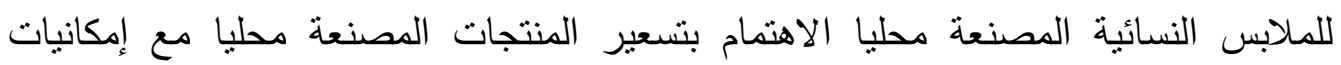

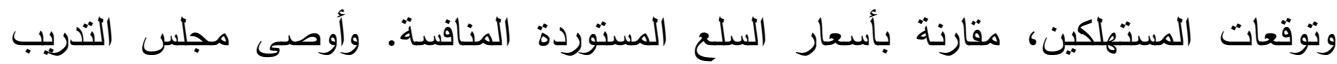

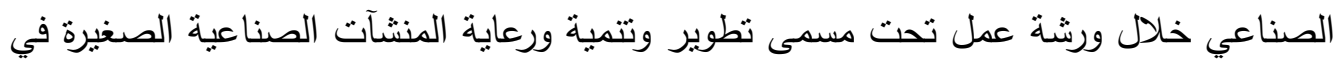

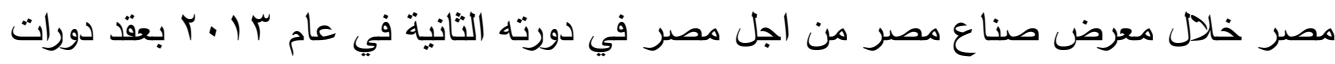

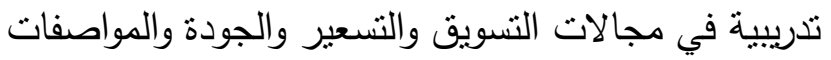


ويحتل التدريب موقعاً محوريا وأساسياً في المؤسسات والمنظمات الحديثة، ويشكل العمود

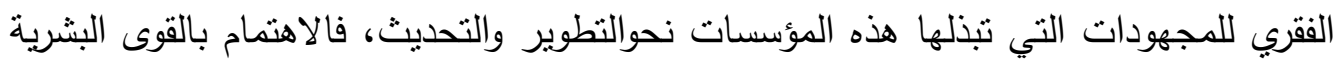

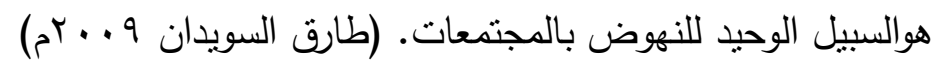

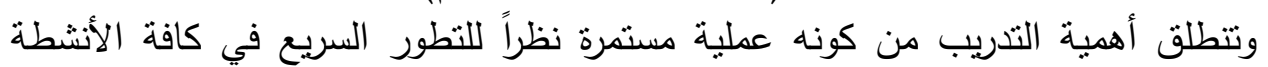

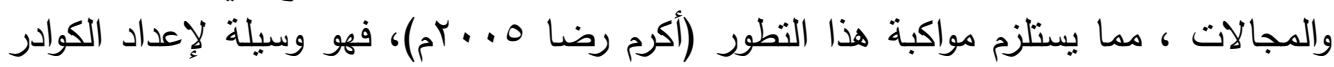

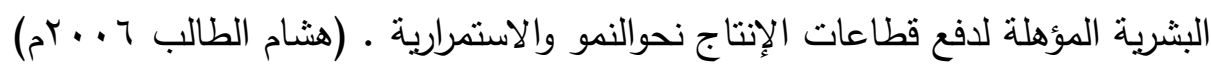
مشكلة البحث: البثة لافع ا. ما التصور المقترح لأعداد البرنامج التدريبي لتعلم كيفية نسعير الملابس الجاهزة من خلال حساب التكاليف؟ r. ما فاعلية البرنامج التدريبي المقترح على رفع المستوى المعرفي للخريجين لتسعير منتجات الملابس الجاهزة من خلال حساب التكاليف؟ r. ما فاعلية البرنامج التدريبي المقترح على رفابل رفع مسنوى المهارة الذهنية للخريجين لتسعير

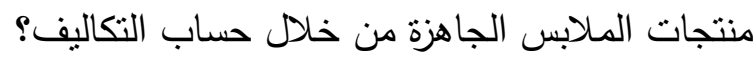
أهداف البحث :يهدف هذا البحث الى اهن: 1. تصميم وتجريب برنامج تدريبي لتسعير الملابس الجاهزة من خلاف لإه حساب التكاليف للخريجين الكليات المتخصصة وذللك للمساهمة في رفع كفاءة الخريج بما يؤهله لمستقبل مهني ناجح r.قياس فاعلية البرنامج التدريبي في تتمية المعارف لاى للخريجين على لتسعير منتجات

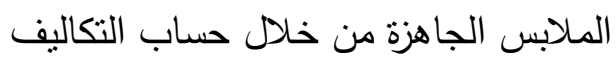
r.قياس فاعلية البرنامج التدريبي في تتمية المهارة الذهنية لدى للخريجين على لتسعير

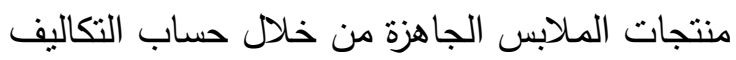

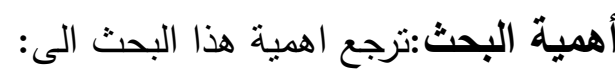

ا ـ يساهم في تتمية معارف ومهارات المتدربين على كيفية الهية تسعير منتجات المالابس الجاهزة

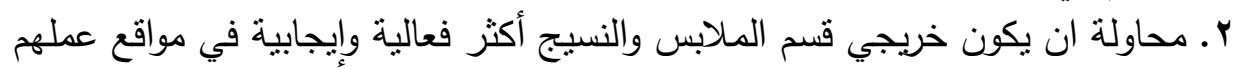

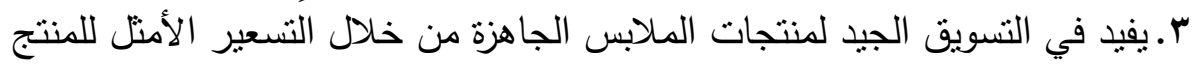

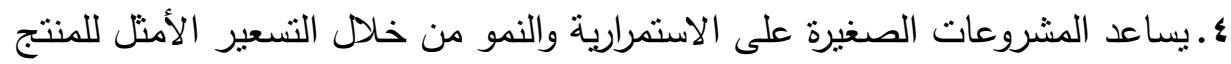

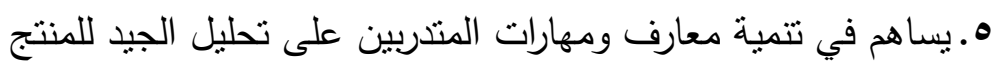

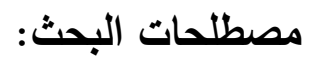
1. الفعالية Effectiveness: القدرة على إنجاز الأهداف أوالمدخلات لبلوغ النتائج المرجوة

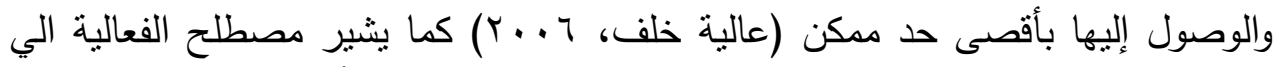

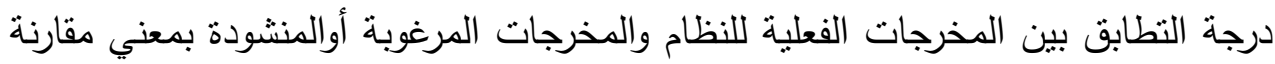

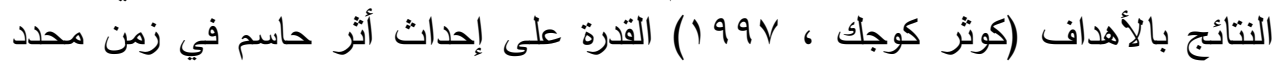

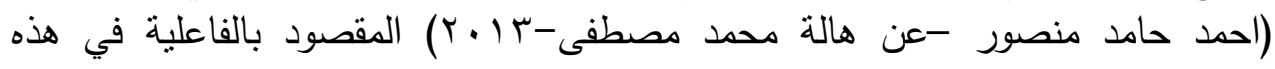


الدراسة هو تحديد الأثر المرغوب أوالمتوقع الذي بحدثه البرنامج المقترح بغرض تحقيق

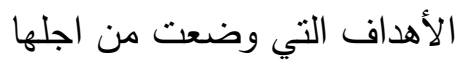

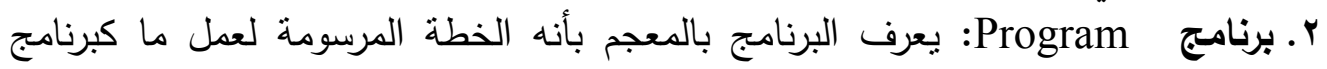

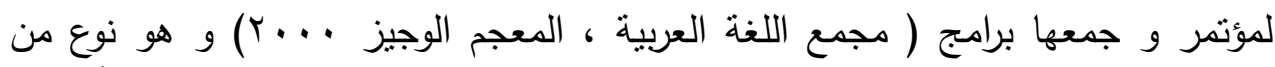

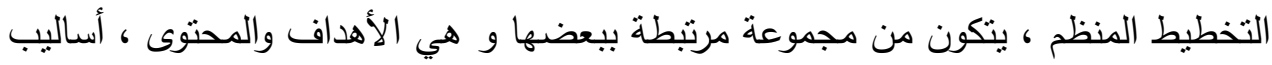

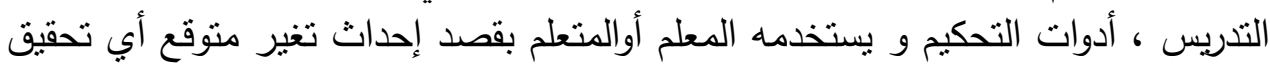

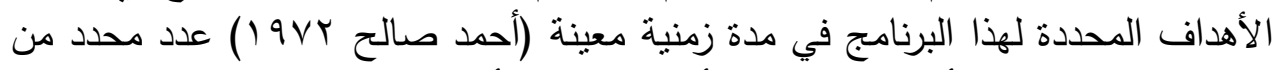

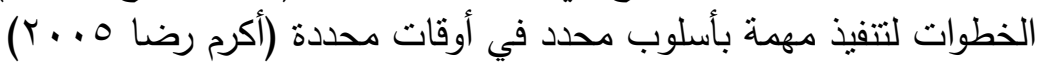

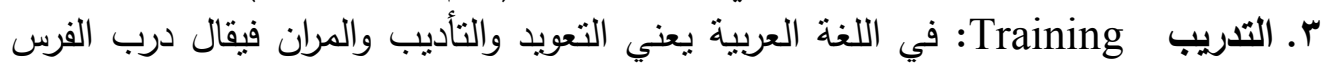

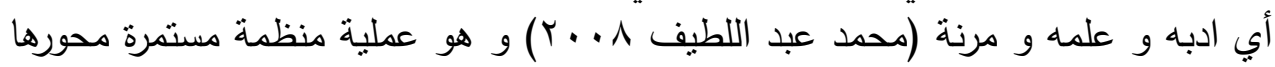

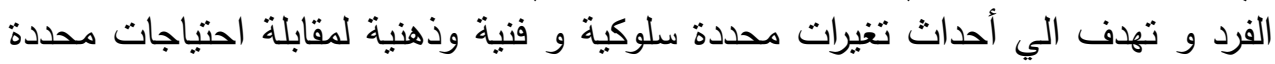

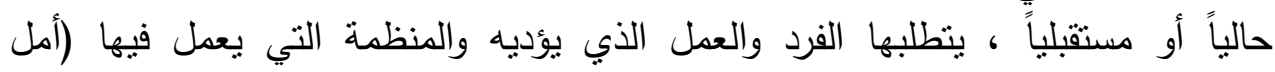

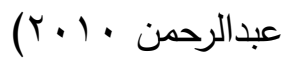
؛. البرنامج التدريبي Training Program : و هو نشاط متجدد و مستمر يبدأ بالتخطيط

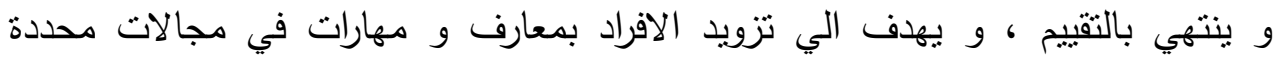

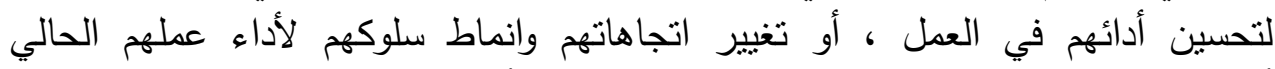

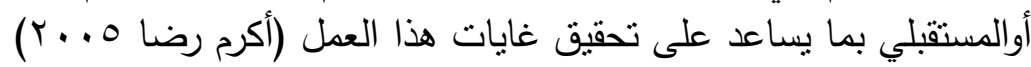

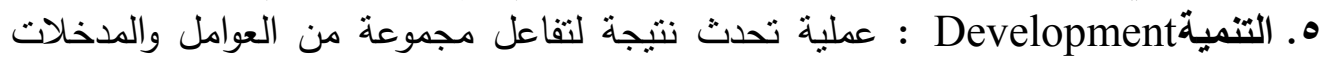
المتعددة من اجل الوصول الي تحقيق تأثيرات و تشكيلات في حياة الانسان في سياقة

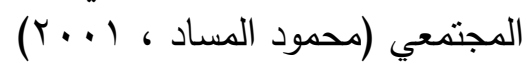

7 المعارف Knowledge: مجموعة من الحقائق والمعلومات والمفاهيم (محمود المساد ، المباد

(r...)

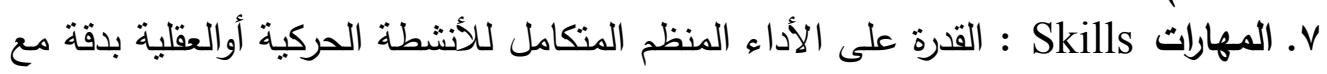

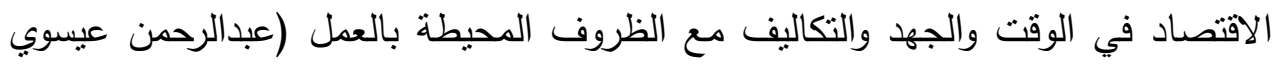

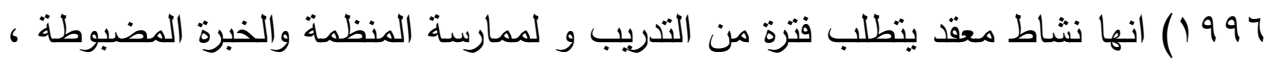

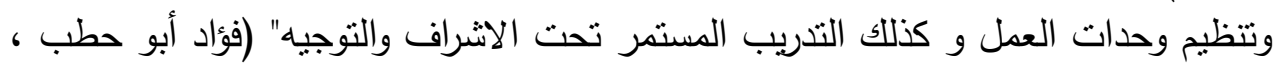

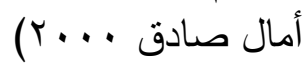

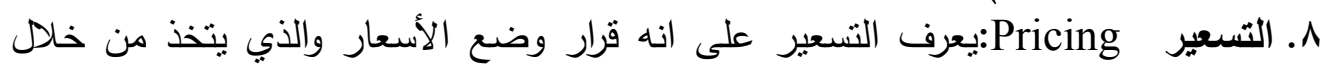

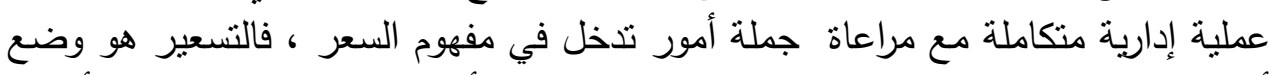

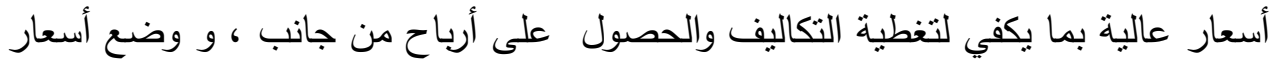

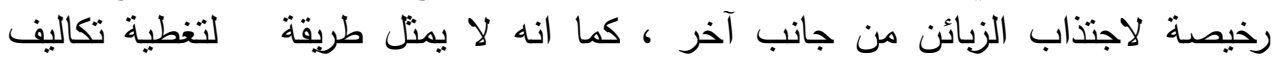

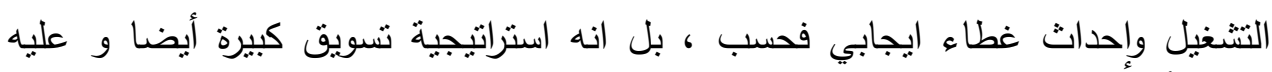

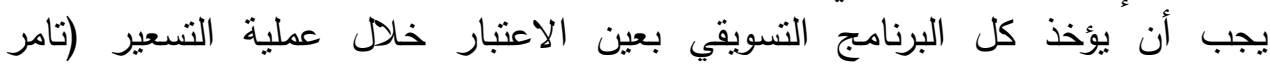

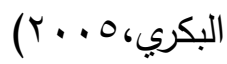


9. الملابس الجاهزة Readymade Garments : هي السلعة الجاهزة من الاقمشة المختلفة

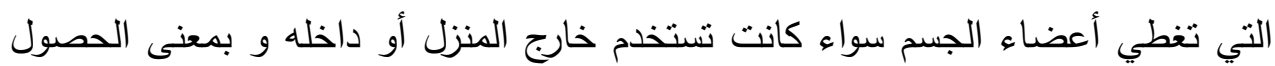
عليها من الأسواق تامه الصنع ، و تقوم بإنتاجها المصانع الخاصة بإنتاج الملابس (أسامة

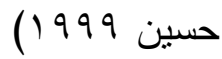

• 1 .حساب تكاليف Costing : هي تجميع و تخصيص و تحليل لبيانات تكلفة الإنتاج

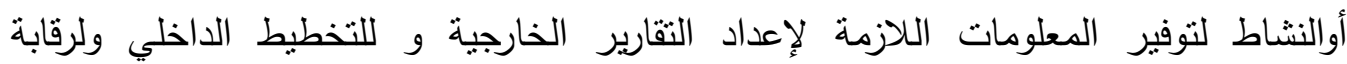
العمليات الجارية و لاتخاذ القرارات الخاصة (محمد الفيومي •99 (19 )

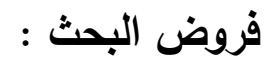

ا ـ البرنامج التدريبي المقترح له فاعلية في التسعير منتجات الملابس الجاهزة

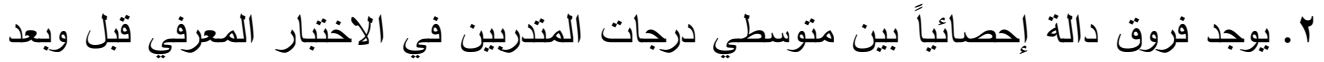
تطبيق البرنامج لصالح التطبيق البعدي دوبي دئي r. يوجد فروق دالة إحصائياً بين متوسطي درجات المبني المتدربين في الاختبار المهارى قبل وبعد

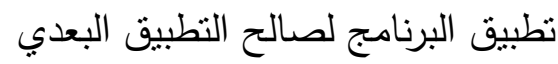

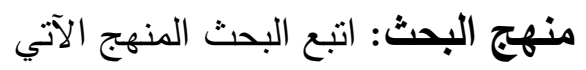
المنهج شبة التجريبي: في الدراسة التجريبية التطبيقية للبحث ، تعتمد على تصميم المجموعة

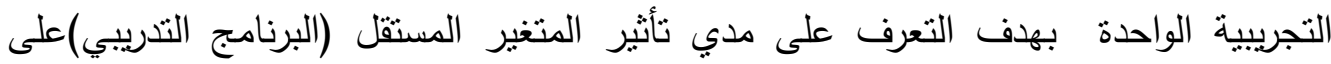

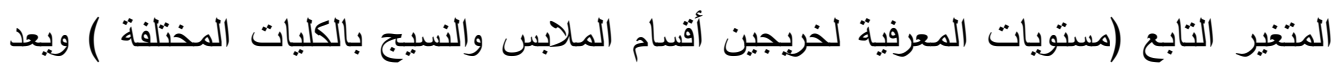

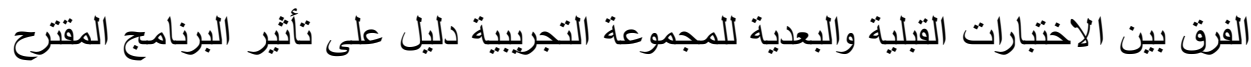

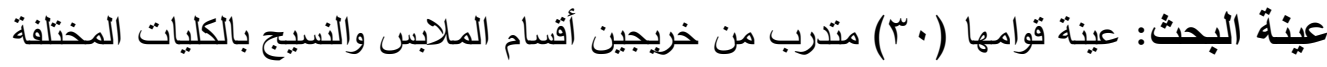

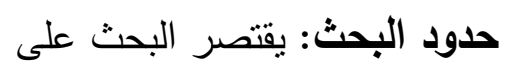

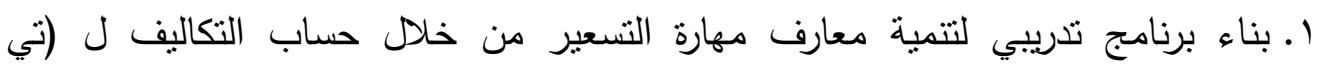

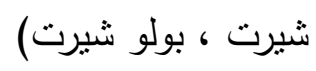

r. نطبيق البرنامج التدريبي لنتمية معارف مهارات لخريجين أقسام الملابس والنسيج بالكليات

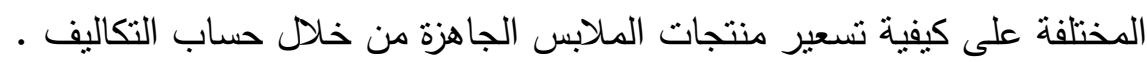
أدوات البحث:

ا ـ استمارة استطلاع رأي المتخصصين في مجال التسعير منتجات الملابس الجاهزة . r. استمارة تحكيم لخبراء متخصصين في تصميم البرامج التدريبية .

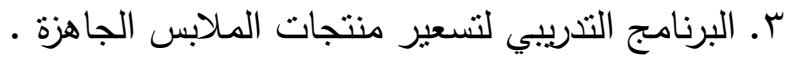

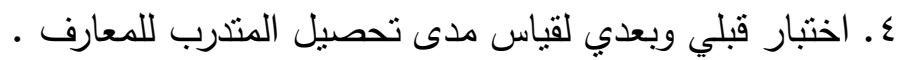

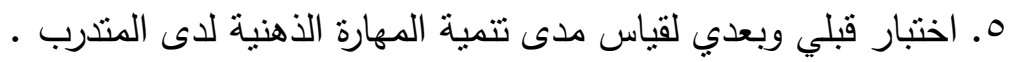


التمهيد: يعد العنصر البشري من العناصر المهمة التي تحيا به منظمات الأعمال، كما يعد

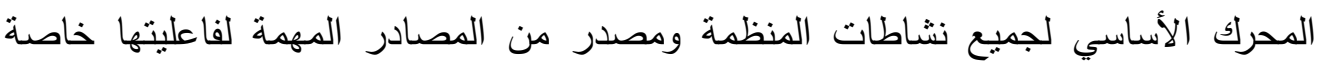

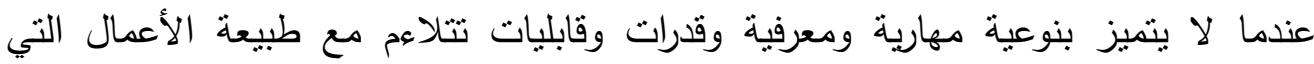

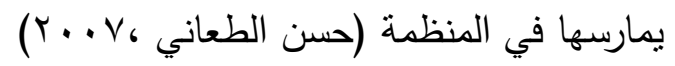
وتعتبر وظيفة التدريب في منظمات الأعمال الحديثة من أهم مقومات التتمية التي تعتمدها هذه

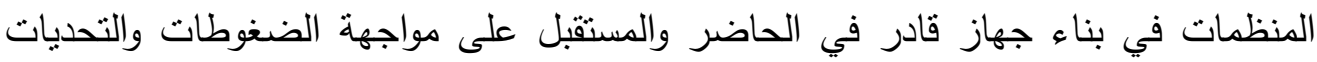

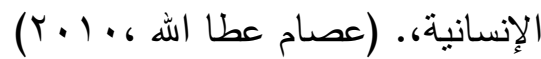
فالتدريب المستمر للموارد البشرية بمختلف فئاته يعتبر من أهم مقومات ومستلزمات التطوير

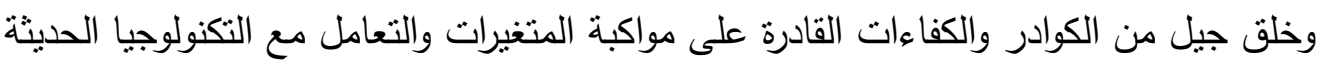

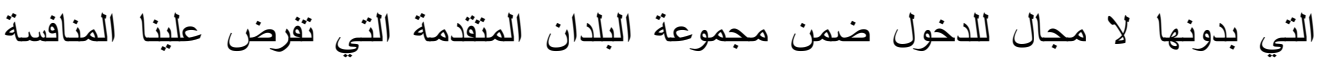

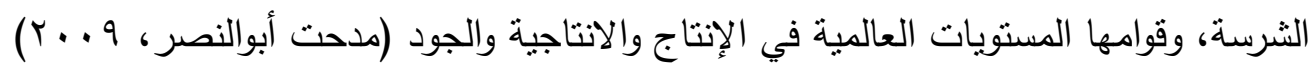

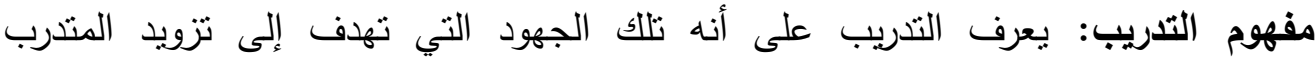

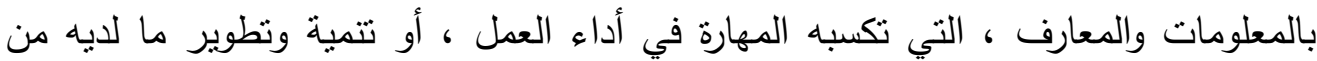

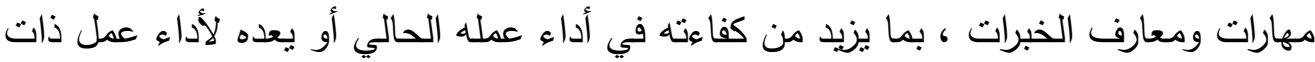

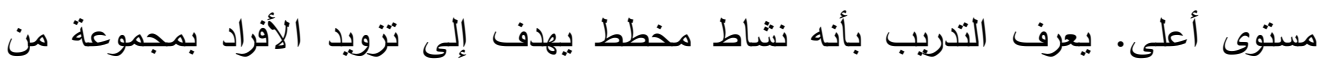

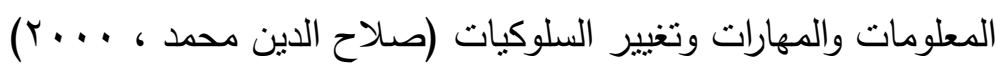

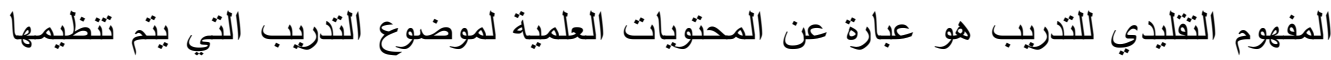

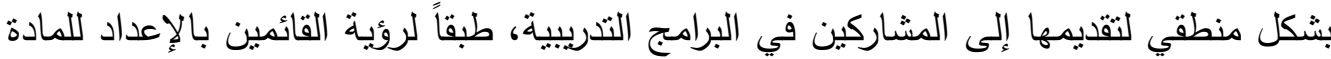

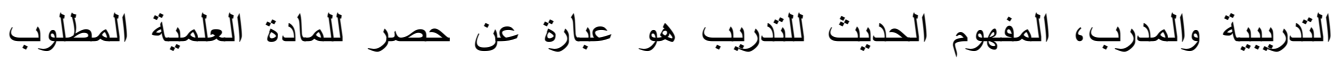

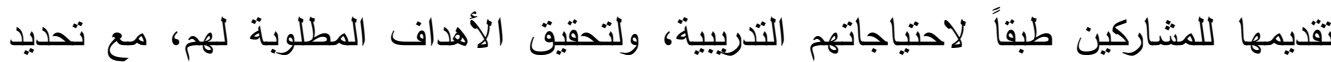

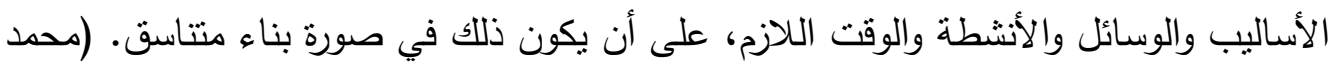

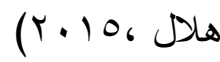
أهمية التدريب: أصبح التدريب أكثر من مجرد المحتويات التفصيلية للموضوعات التدريبية،

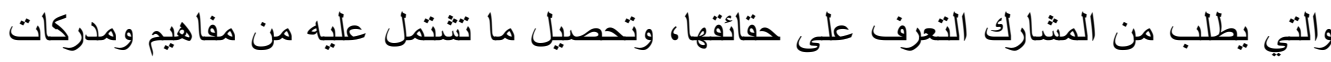

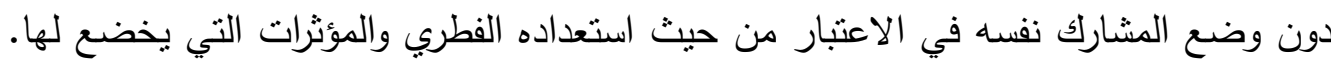

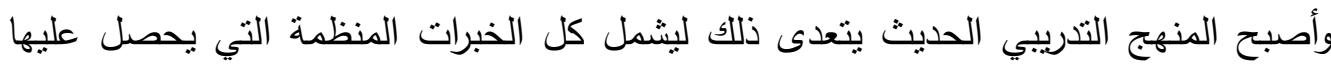

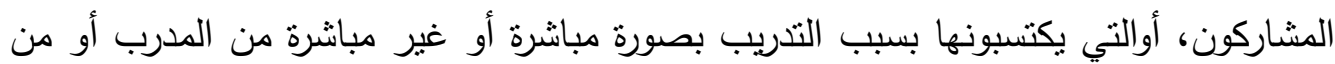

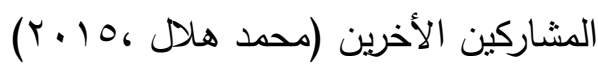


أ. أهمية التدريب للمنظمة: تحقق العملية التدربية الفاعلة المصممة وفقا لمبادئ التعلم

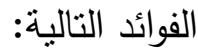

ا. ارتفاع معدل الإنتاجية والأداء التنظيمي من خلال الوضوح في الأهداف وطرق وإجراءات

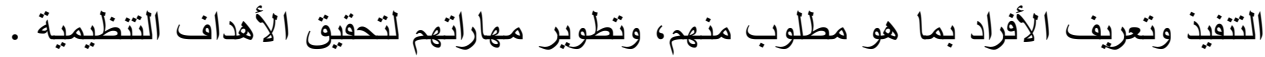

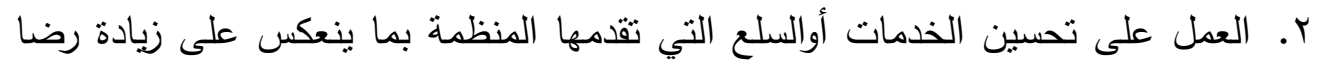

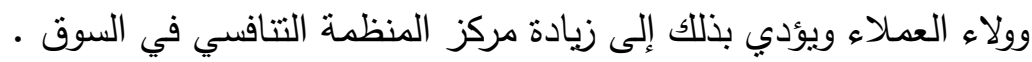

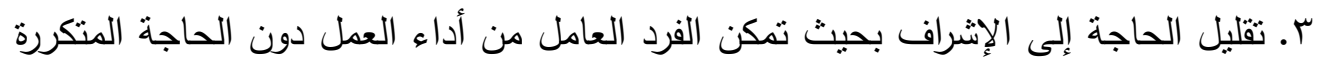

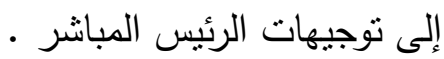

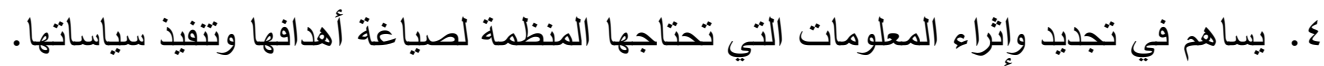
ه. تخفيض معدل حوادث العمل، وتقليل نسبة إهمال العاملين كنتيجة لزيادة وعيهر .

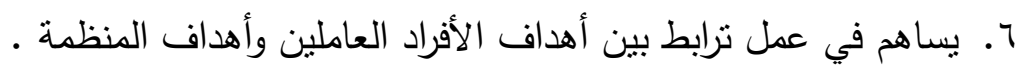

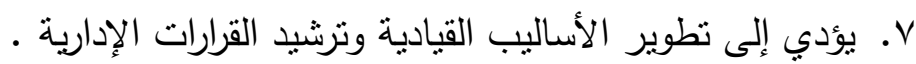

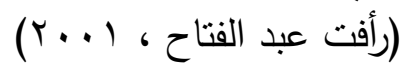
ب. أهمية التدريب للأفراد العاملين ا ـ يكسب الأفراد العاملين معارف ومهارات واتجاهات ذات التات علاقة مباشرة بالعمل مما يطور

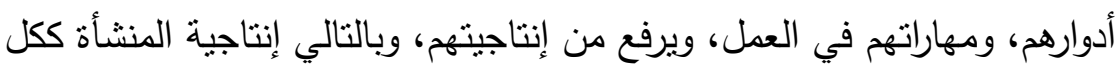

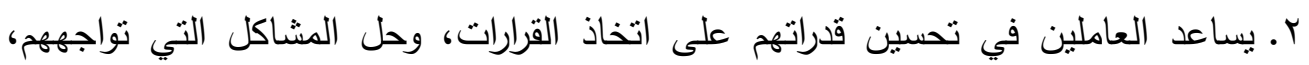

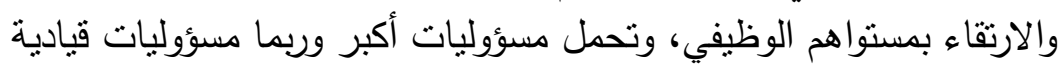

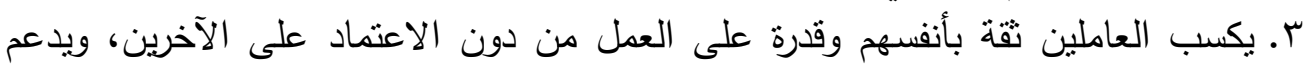

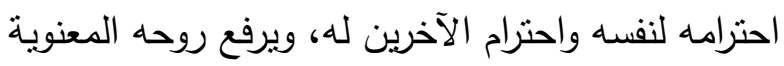

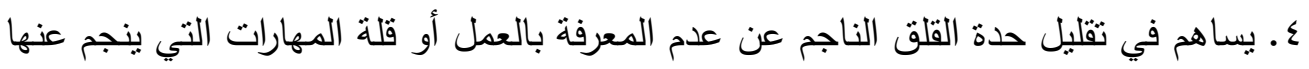
ضعف في مستوى الأداء ه. يساعد الأفراد في تطوير مهارات الاتصال والتفاعلات مع بيئة العمل بما يحقق

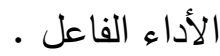
7 ا يساهم التدريب في الإقلال وتسهيل الإشراف، فالموظف أوالعامل المتدرب جيد التقل نسبة

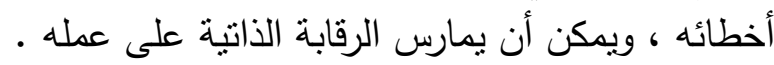

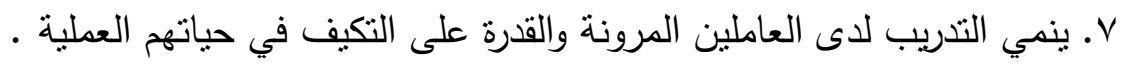

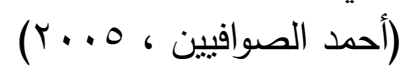

أهداف التدريب: الهدف التدريبي هو بيان مكتوب يصف نتيجة مقصودة من منطلق أداء

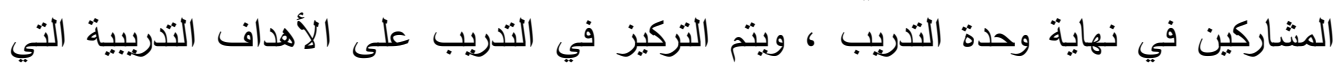

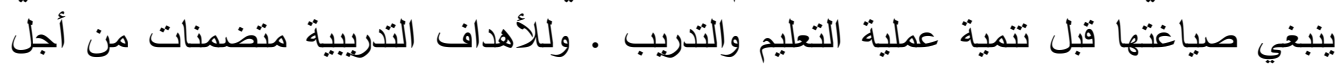
المحتوى والمنهج والتقييم ، ولذلك ينبغي تكريس الوقت والعناية بكتابتها وصياغتها (محمد هلال 
يذكر (عصام عطا الله ، • • ب) أن" الأهداف الرئيسية لعملية التدريب تتمثل في زيادة المعرفة

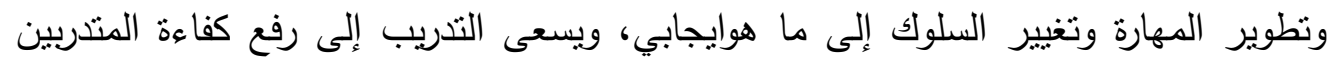

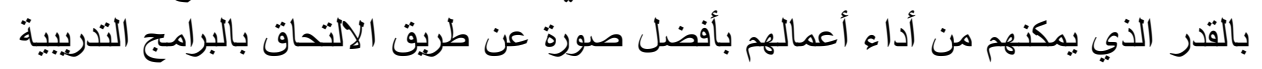

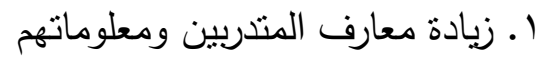

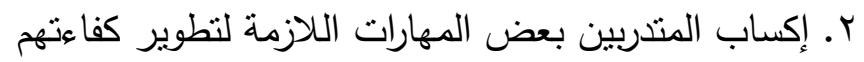

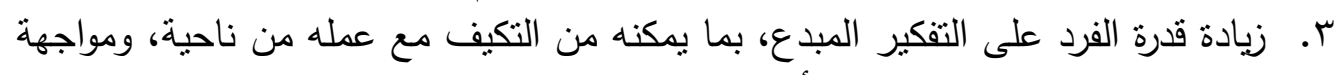

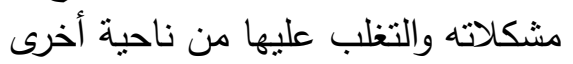

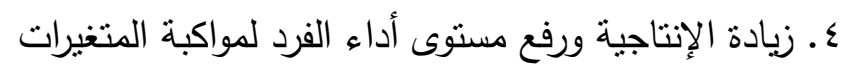

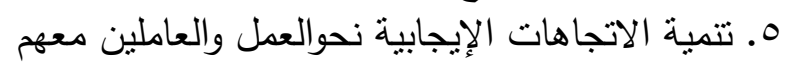

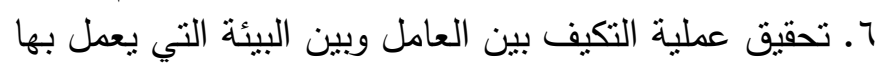

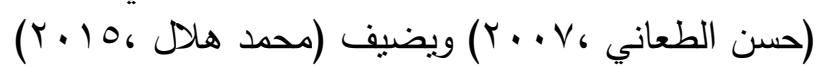

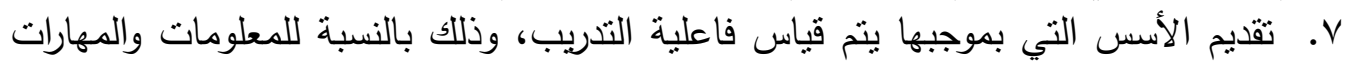

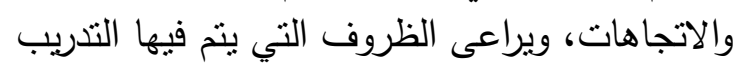

التسعير

يعتبر التسعير أحد أهم القرارات الاستراتيجية التي تؤثر على نجاح أو فنشل أي مؤسسة

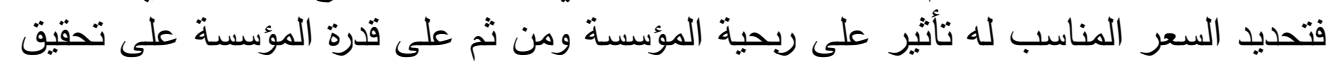

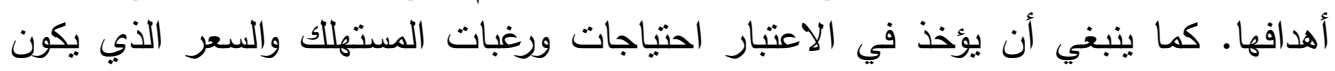

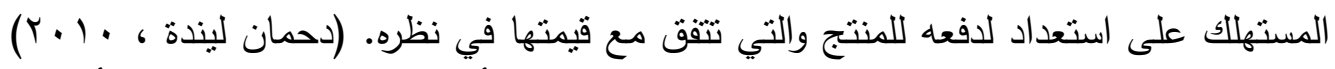

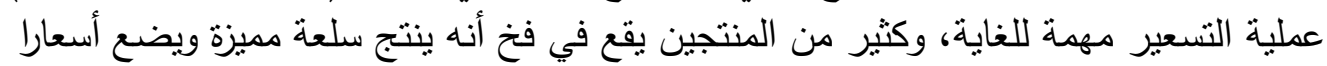

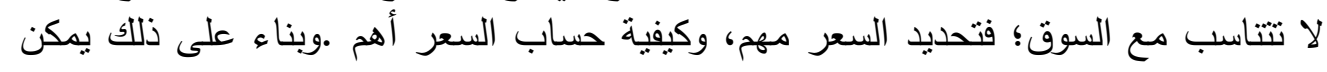

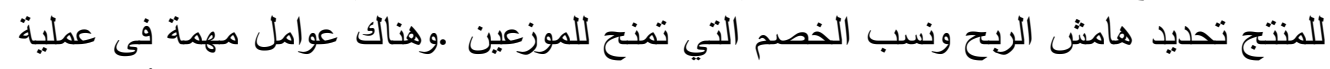

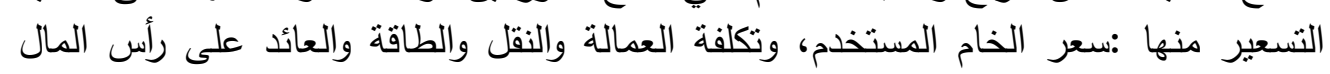

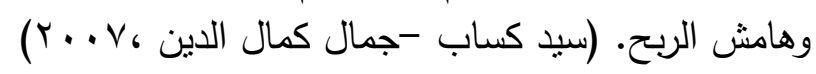

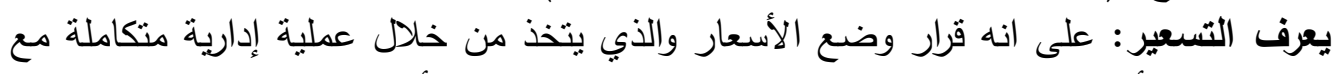

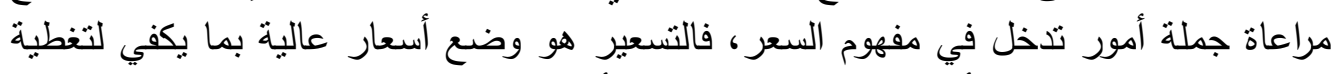

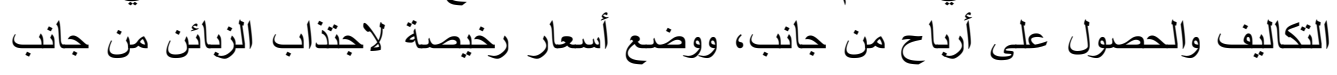

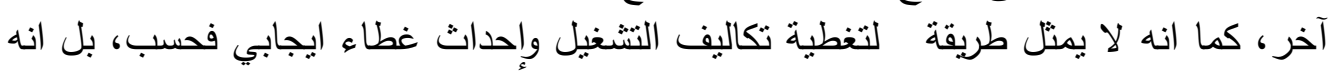

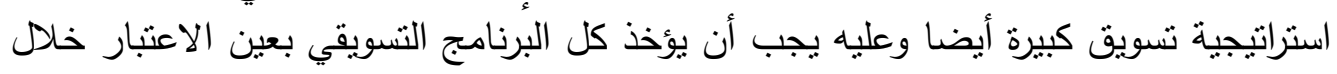

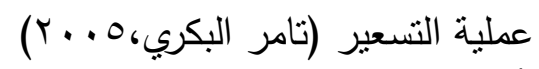

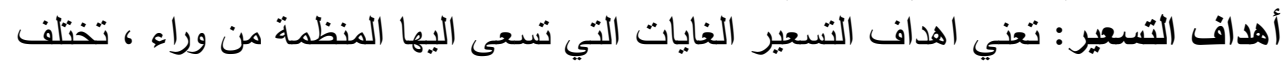

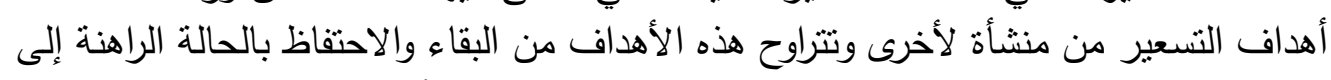

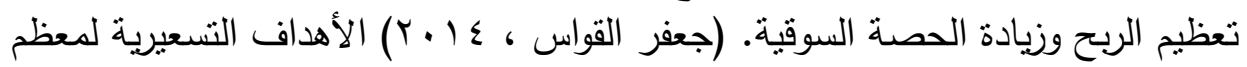

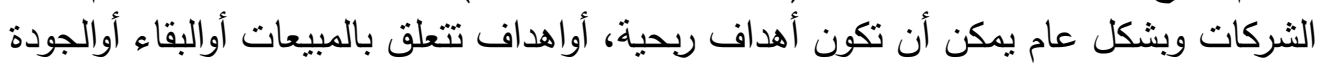

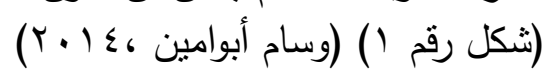


زيادة التدفقات النقدية، أوالمحافظة على الوضع الراهن أوالمحافظة على مستوى عالي شكل رقم أهداف التسعير

أهداف التسعير

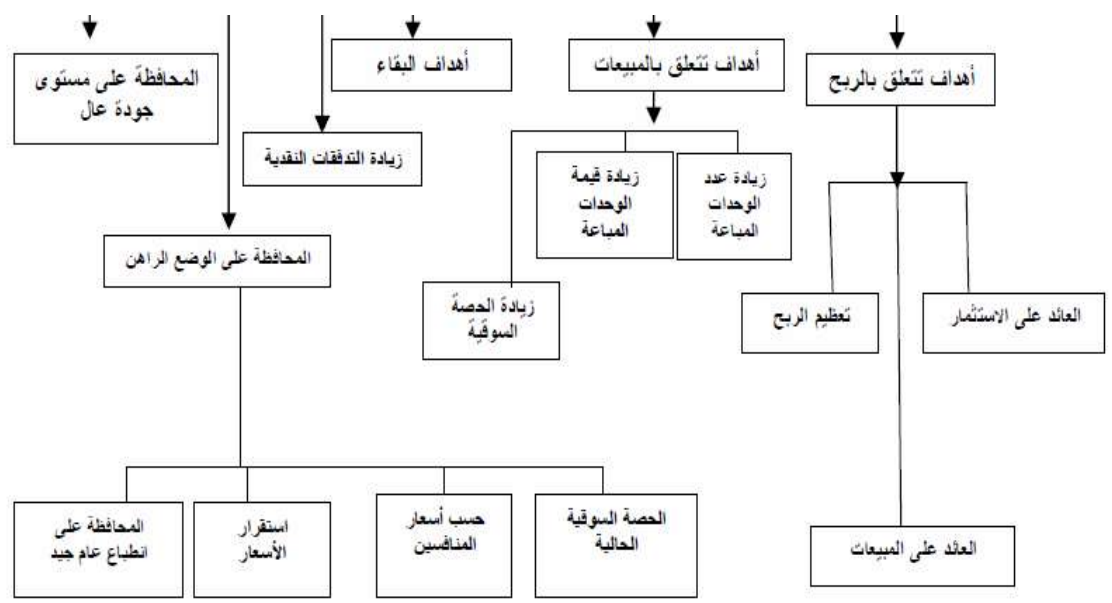

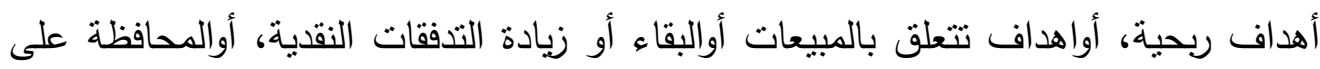

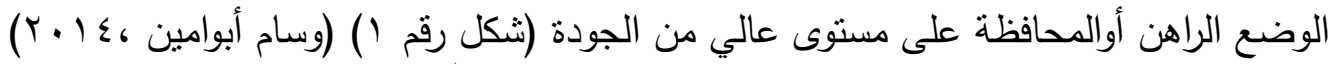

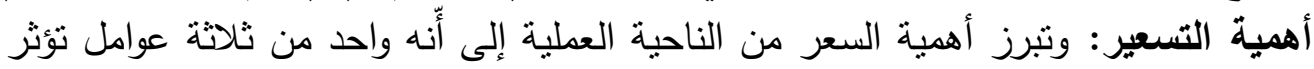

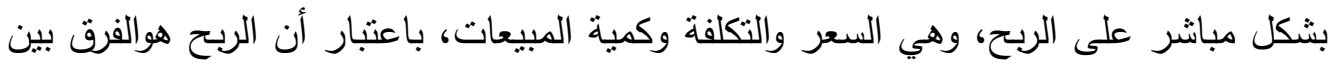

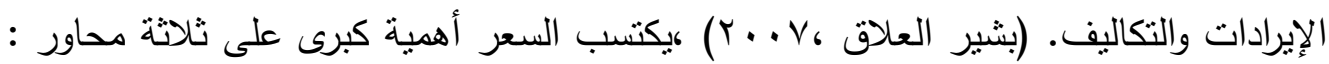

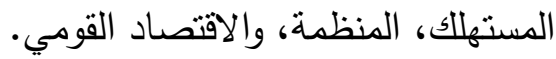

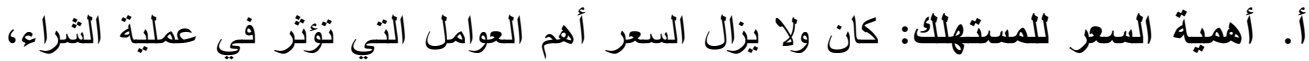

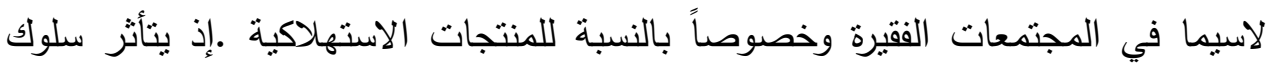

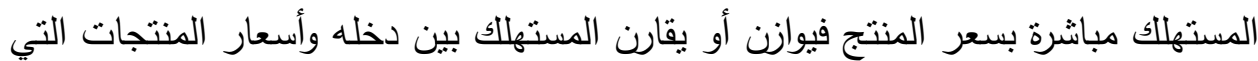

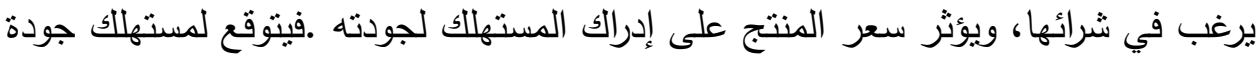
أعلى للمنتج الأعلى سعراً، ذلك فئل لأن السعر يمثل إلى الدراك الواجهة المعبرة عن جودة المنتج في شكل رقمي. ب. أهمية السعر لمنظمة الأعمال: يستمد السعر أهميته من أنه العنصر الذي يعول عليه في

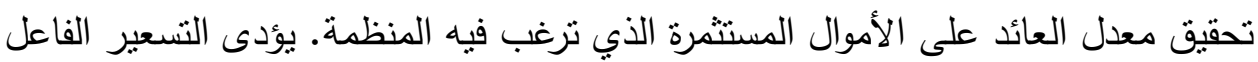

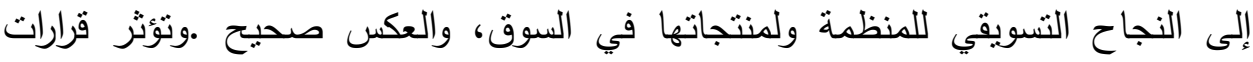
التسعير على مختلف وظائف المنظمة. 
ت. أهمية السعر للاقتصاد القومي: يلعب السعر في الوقت الحاضر دوراً رئيساً كوسيلة لتنظيم الإنيا

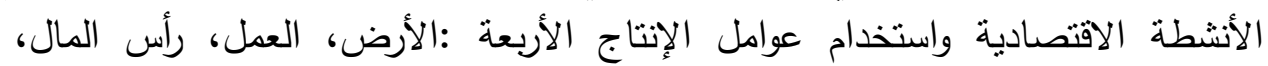

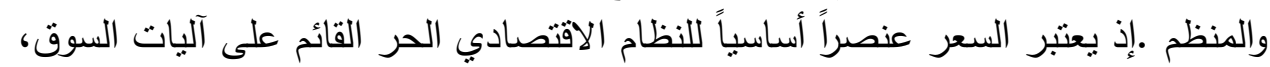

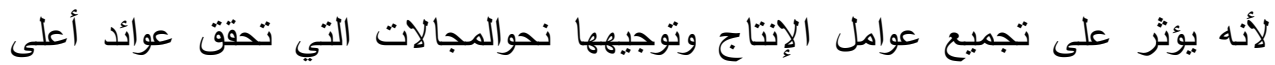

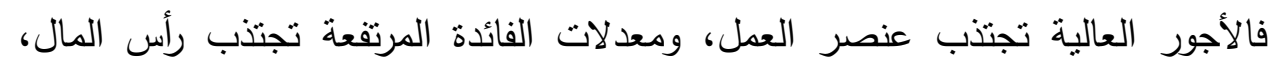

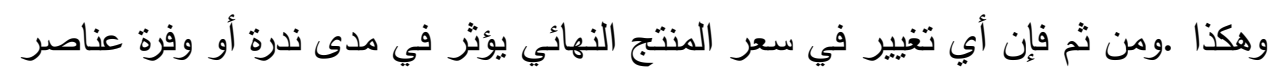

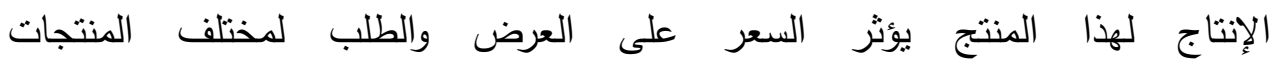

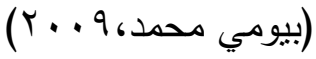

$$
\begin{aligned}
& \text { استراتيجيات التسعير : }
\end{aligned}
$$

النفاذ إلى السوق: تحدد الشركة أسعار منخفضة حتى تنتطيع تحقيق النمو والحصول على النصيب الأكبر كشط السوق: تحديد سعر مرتقع للسلع على أساس حصول الثركة على أقصى ما يمكن من

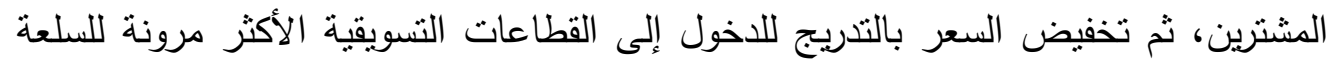

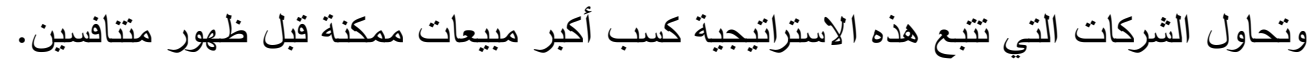

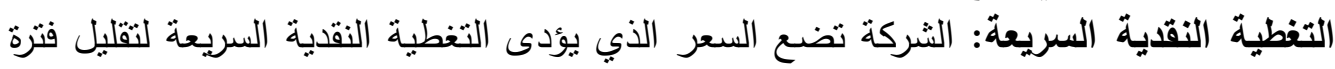

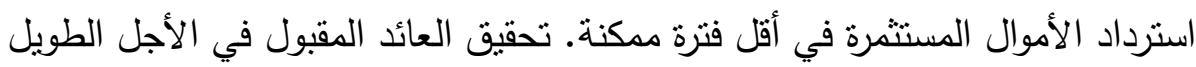

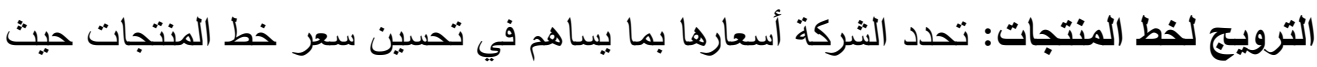

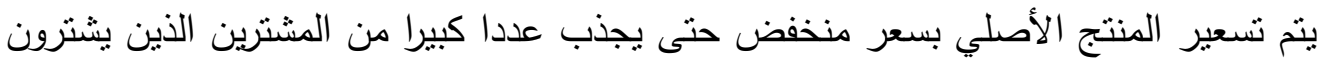

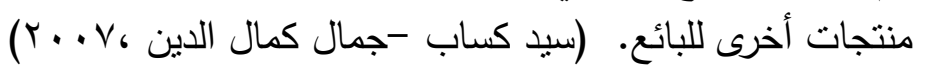
سياسات التسعير:

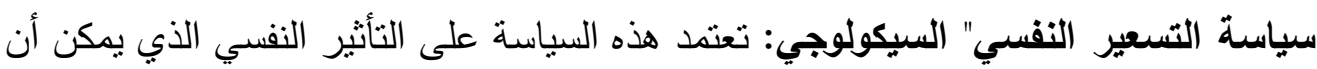

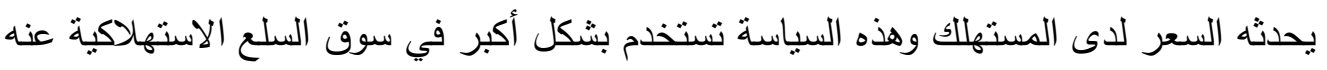
في سوق السلع الصناعية سياسة التسعير الترويجي: يقصد بالتسعير الترويجي الذي يكون الهدف الأساسي منه العمل

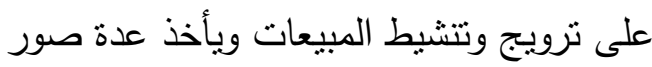

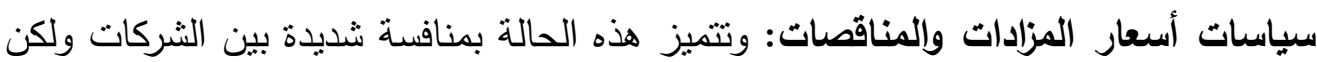

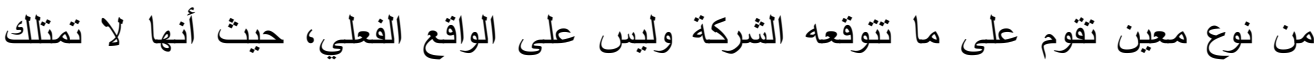

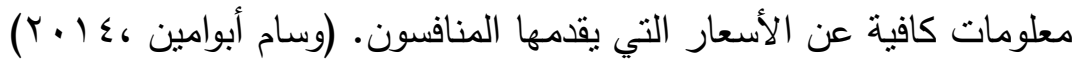

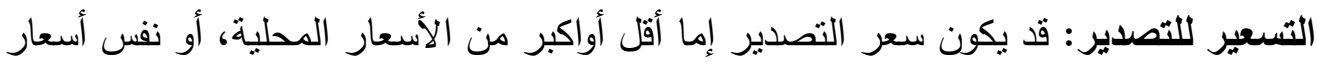

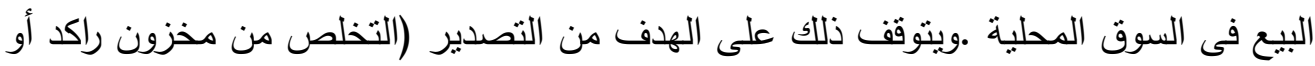

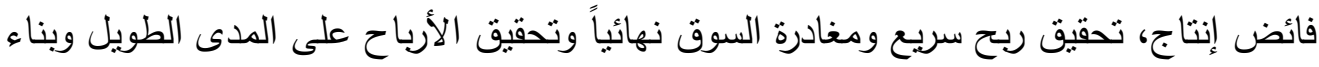
حصة سوقية كبيرة)، 
تتعلق هذه العروض بمراحل انتقال ملكية المنتجات من المصدر إلى المستورد، وتحديد المسئول

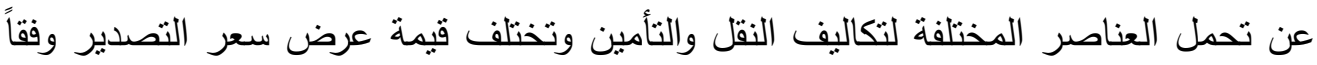

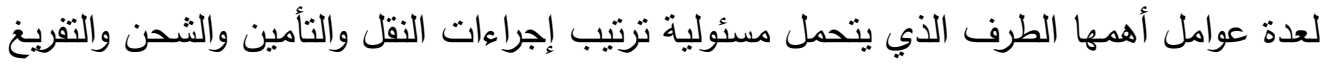

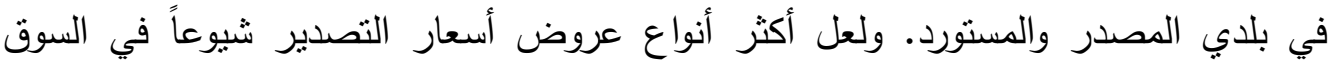

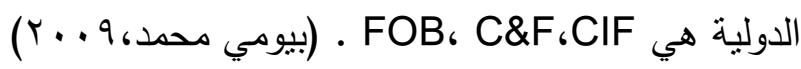
طرق التسعير

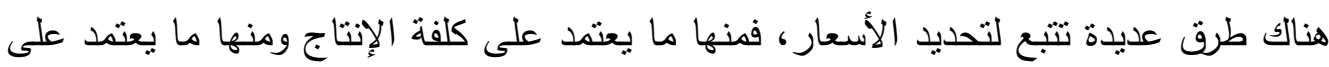

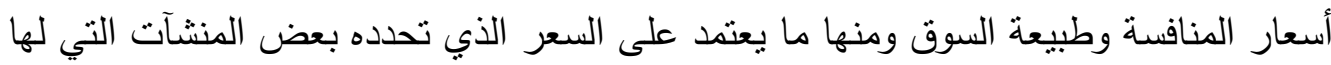

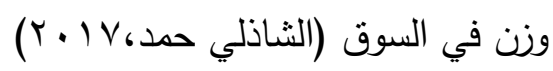

التسعير على أساس المنافسة: تحدد النظرية الاقتصادية عدة مجالات تقليدية للسوق تميل فيها

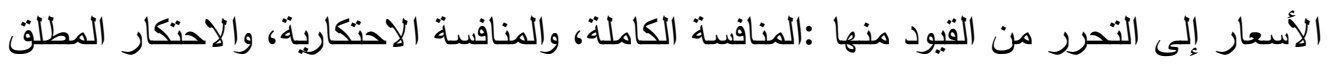

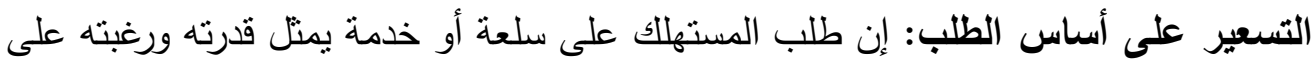

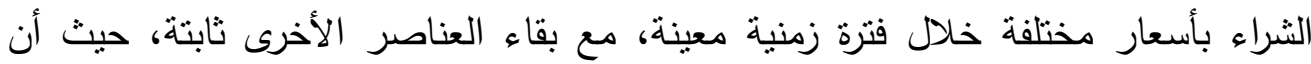

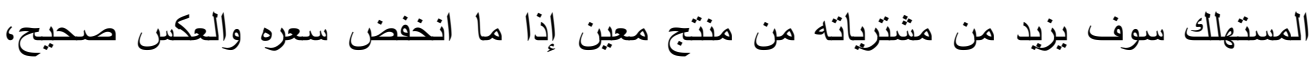

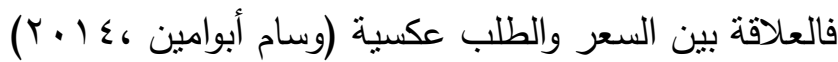

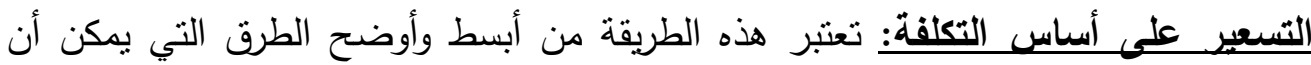

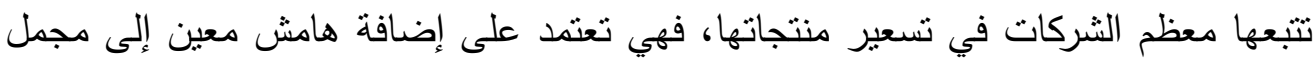

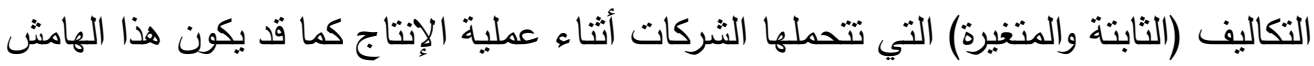

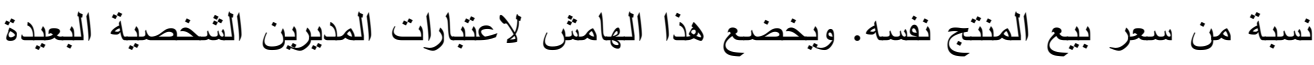

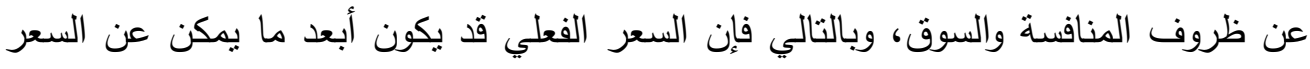

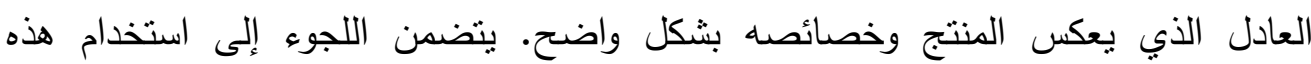

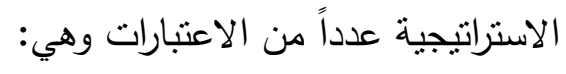

ا. الثعور بالعدالة الاجتماعية من قبل الثركة والزبائن على حد سواء، والحصول على عائد

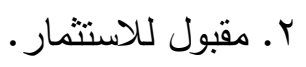

r. اعتماد التسعير على مصادر جاهزة للمعلومات دون الحاجة الحاجة للاهتمام بدراسة حركة

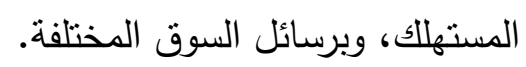

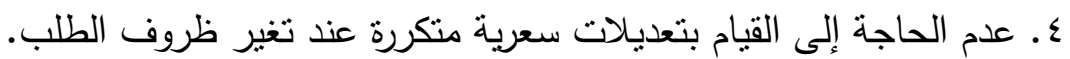

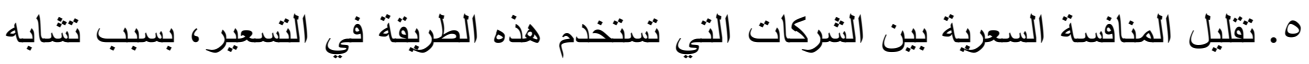

$$
\text { الكلف والهوامش الربحية فيها }
$$

تتص هذه الطريقة على إضافة نسبة مئوية معينة وتأخذ المعادلة الثكل التالي:

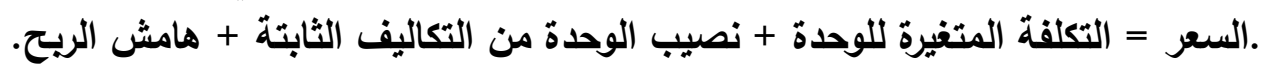

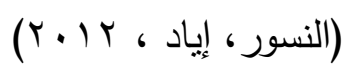


ثانيا: الإطار التطبيقي (إجراءات البحث (الدراسة النطبيقية))

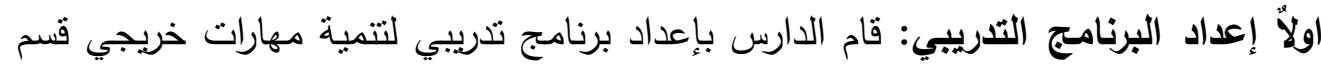

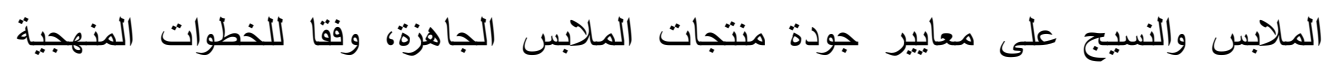

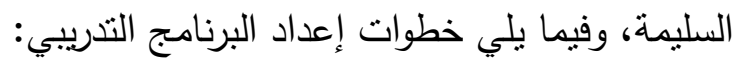

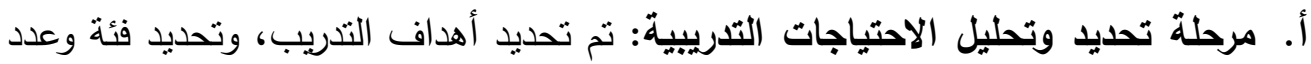

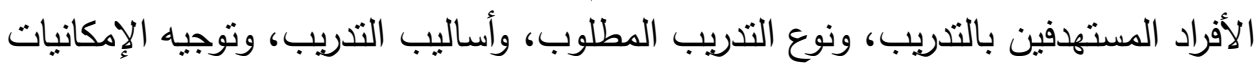

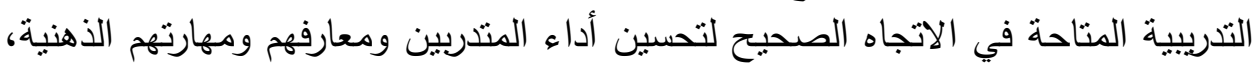

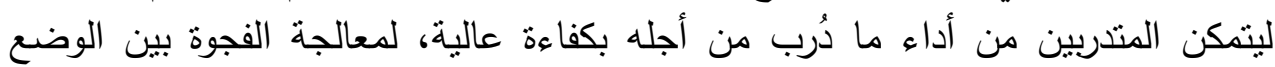

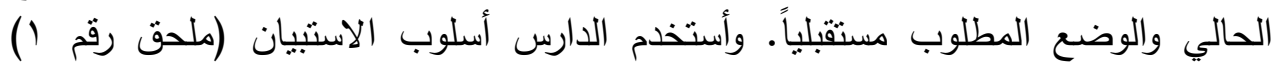

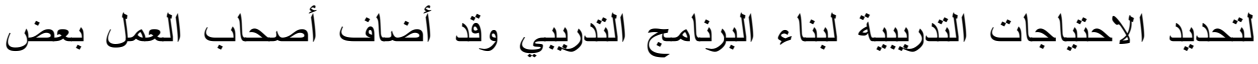

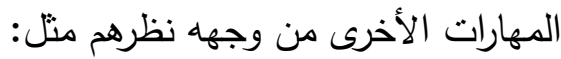

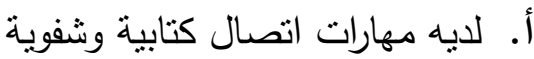
ب.ان يكون قادر على التفاوض. ت. مرحلة تخطيط التدريب: وأستخدم الدارس أسلوب الاستنيان (ملحق رقم ؟) لتحكيم البرنامج

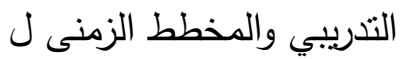
ا ـ تحديد أهداف البرنامج التدريبي. r r r تحديد محتوى البرنامج التدريبي. r. تحديد مواد التدريب والمادة العلمية.

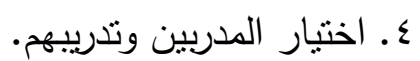
ه. تحديد أساليب ووسائل التدريب والمساعدات التهات التدربيية. 7 7. تحديد زمان ومكان التدريب. V. اختبار المتدربين

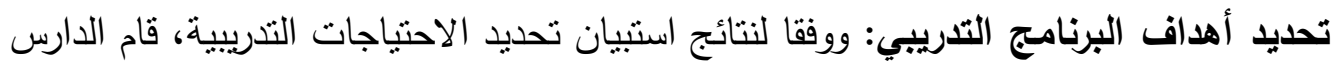

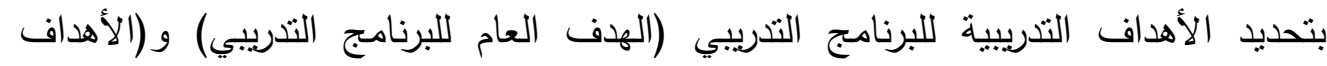

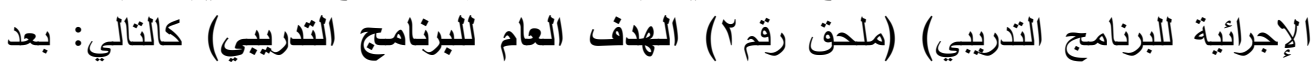

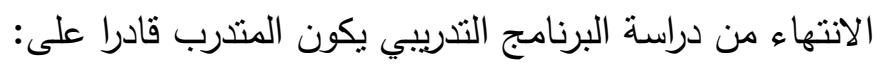

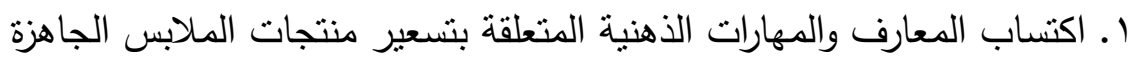

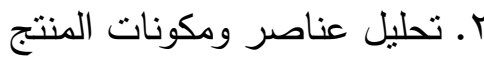
r. حساب تكاليف وتسعير المنتج تحديد محتوى البرنامج التدريبي: وقد قام الدارس بتتظير موضوعات محتوي البرنامج التدريبي

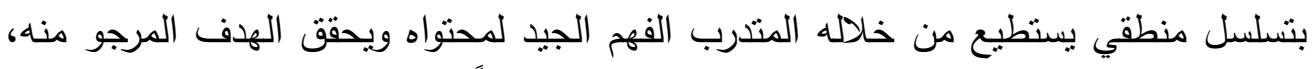

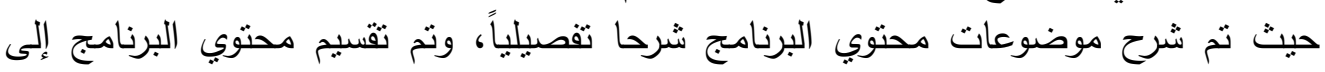
خمس وحدات تدريبية وهي كالتالي 


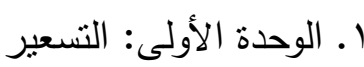

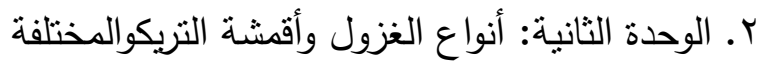

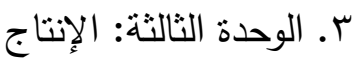

ع. الوحدة الرابعة: القيمة المضافة (المكملات، المستلزمات، الطباعة والتطريز) )

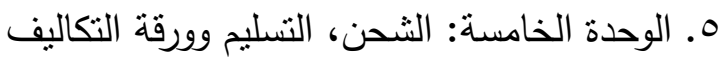

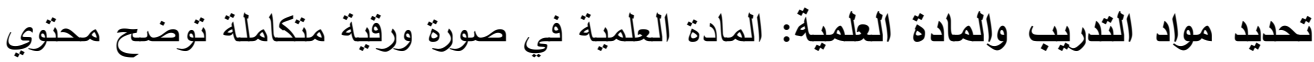

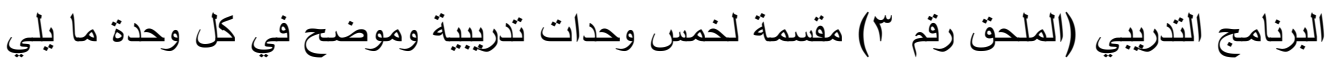
(الجدول الزمني لكل وحدة تدريبية، الهدف العام للوحدة، والأهداف الإجرائية (معرفية، مهاري)،

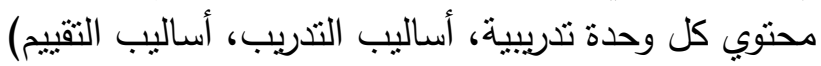

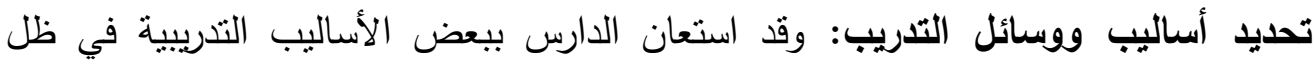

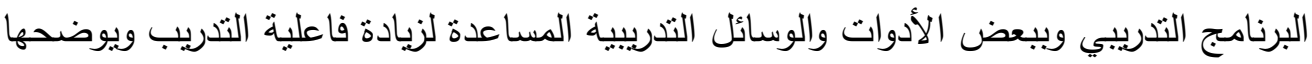

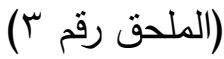

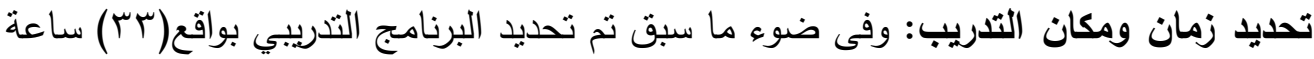

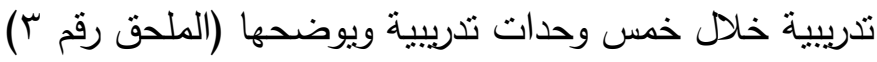

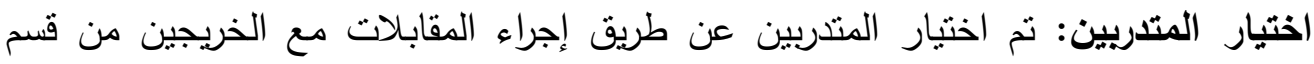

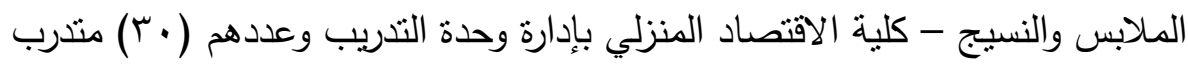

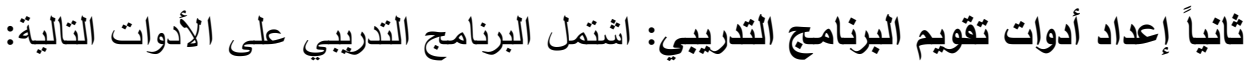

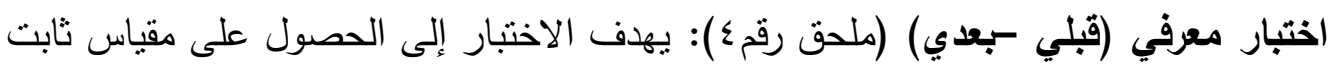

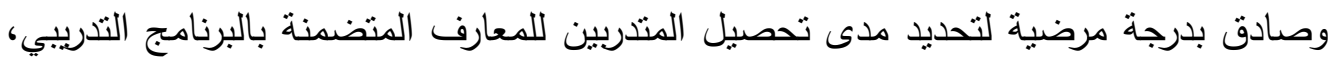

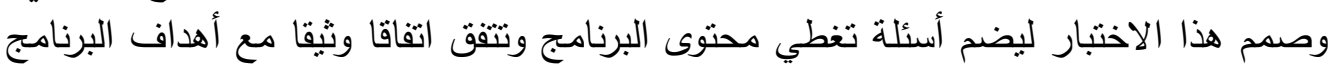

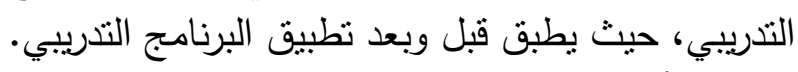

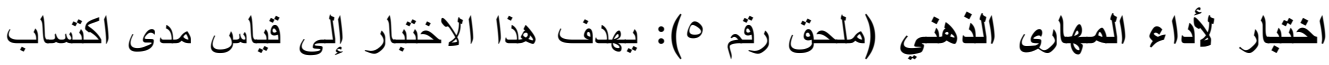

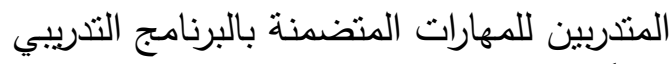

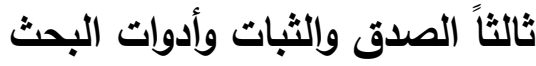

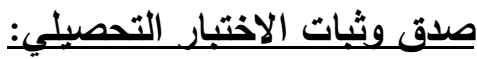

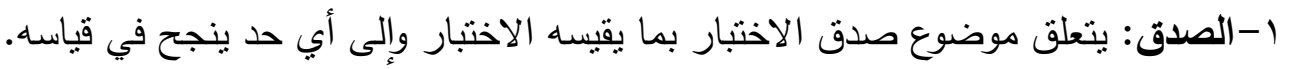

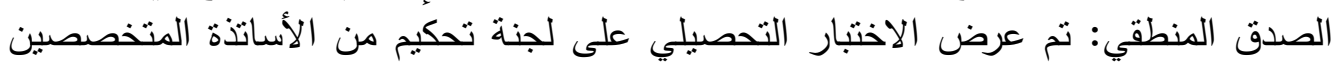

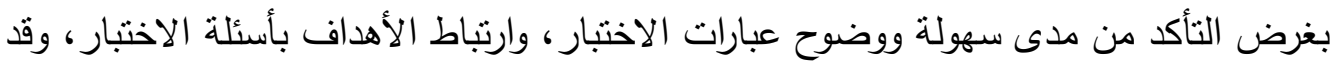

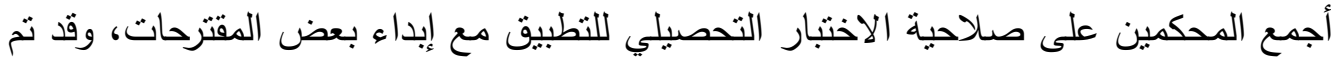

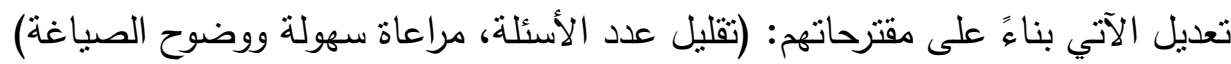

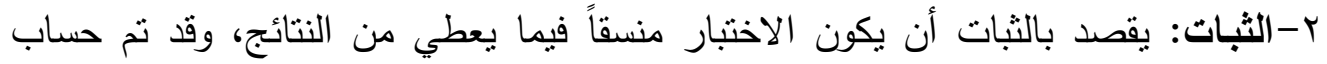
معامل ثبات الاختبار التحصيلي بالطرق النات الآنية: 
أ- الثبات باستخدام التجزئة النصفية: نم التأكد من ثبات الاختبار التحصيلي باستخدام طريقة

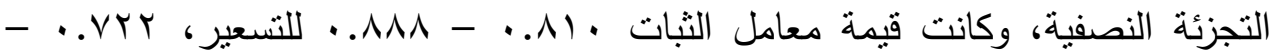
roY

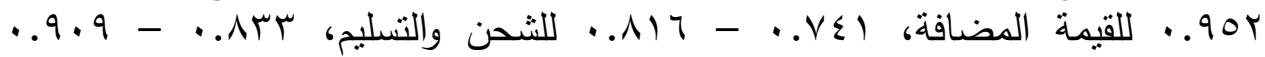

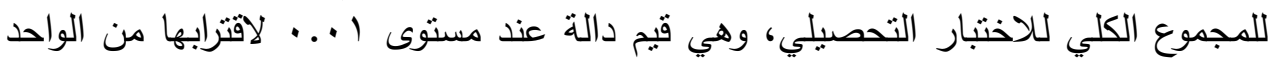

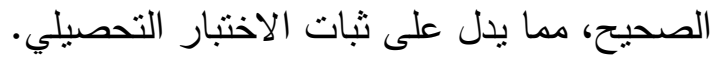

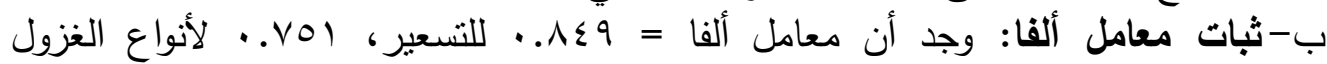

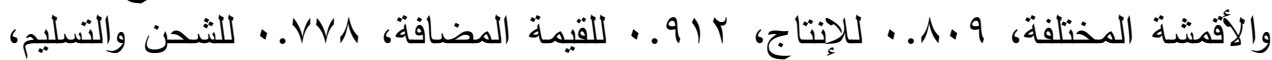

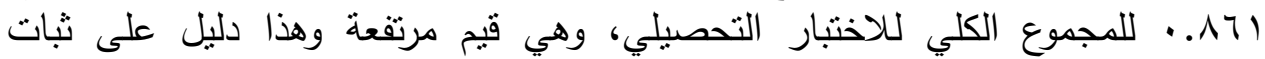

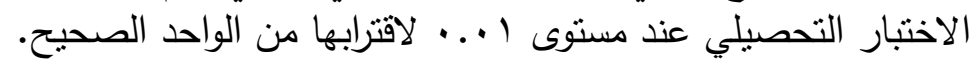

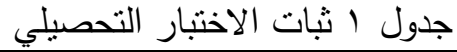

\begin{tabular}{|c|c|c|c|c|}
\hline \multicolumn{2}{|r|}{ التجزئة النصفية } & \multicolumn{2}{|r|}{ معامل ألفا } & \multirow{2}{*}{ ثبات الاختبار التحصيلي } \\
\hline 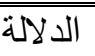 & قيم الارتباط & 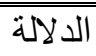 & قيم الارتباط & \\
\hline. .1 & $. . \wedge \Lambda \wedge-. . \Lambda 1$. & $\cdot . \cdot 1$ & $\cdot . \wedge \leqslant 9$ & التسعير \\
\hline 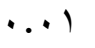 & $. V Q Y-. V Y Y$ & $\cdot . \cdot 1$ & $\therefore$. 01 & أنواع الغزول والأقمشة المختلفة \\
\hline$\ldots 1$ & $. . \Lambda \leqslant \neg-\cdots \vee V V T$ &. .1 & $\cdot .1 \cdot 9$ & الإنتاج \\
\hline$\ldots 1$ & $. .90 Y-. .111$ & $\ldots 1$ &. $.91 \mathrm{r}$ & القيمة المضافة \\
\hline$\ldots 1$ & $\cdot . \wedge 17-. V \leqslant 1$ &. .1 & $\because \vee \vee \wedge$ & الثحن والتسليم \\
\hline$\ldots 1$ & $. .9 .9-. .1 M r$ & $\ldots 1$ & $\cdot .147$ & المجموع الكلي للاختبار التحصيلي \\
\hline
\end{tabular}

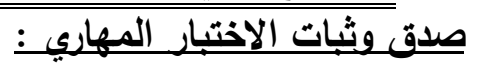
1-(الصدق: (الصدق الإئبار المنطقي): نم عرض الاختبار الصنار على مجموعة من الأساتذة المتخصصين

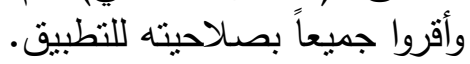

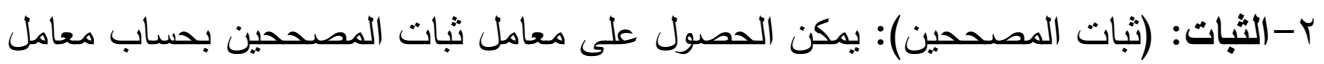

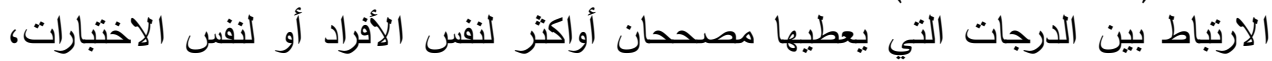

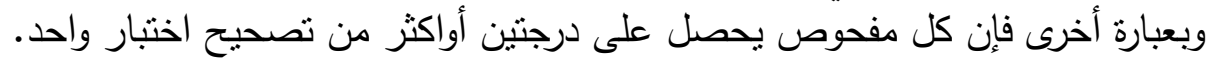

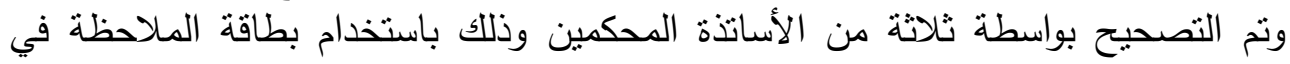
عملية التقويم وقام كل مصحح بعملية التقويم بمفرده.

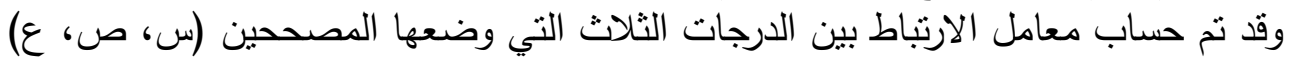

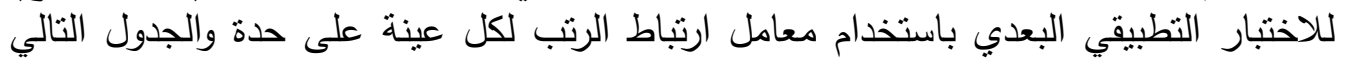
جدول رقم 2 دعامل الارتباط بين المصحدين للاختبار الدهارى

\begin{tabular}{|c|c|c|c|c|c|c|}
\hline ككل & التشليم & القيمة & الإنتاج & والأقمشة المختلفة الغزول & التسعير & المصححين \\
\hline..$\Lambda 1 \%$ & $. .9 . Y$ & $. . V+1$ &..$\vee 7 \varepsilon$ &..$\vee 17$ & ( & س ، ص \\
\hline$\therefore$ VYO & ..V91 & ..$\wedge 7 \varepsilon$ & .911 & $\cdot . \Lambda \cdot r$ & $\therefore V \leqslant 7$ & ع \\
\hline. .101 & $\because v 01$ & $\because . v \cdot v$ &. .191 & .VAY &. .9 .0 & ص ، ع \\
\hline
\end{tabular}


يتضح من الجدول السابق ارتفاع قيم معاملات الارتباط بين المصححين، وجميع القيم دالة عند مستوى ا.... لاقترابها من الواحد الصحيح، مما يدل على ثبات الاختبار النطبيقي

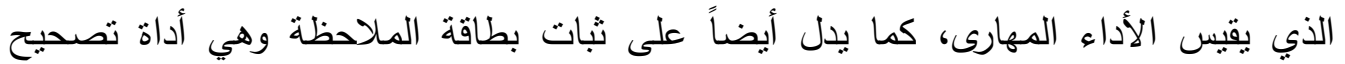

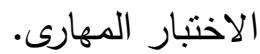
خامساً :إجراءات الدراسة الأساسية: مرحلة تتفيذ التدريب: وقد بدأ تتفيذ التدريب الفعلي

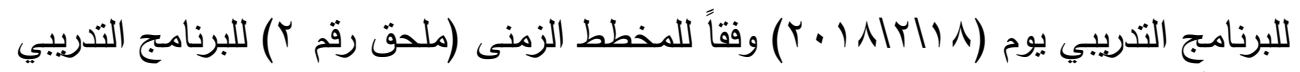

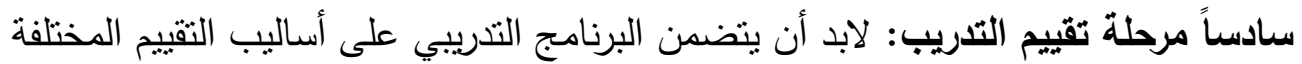

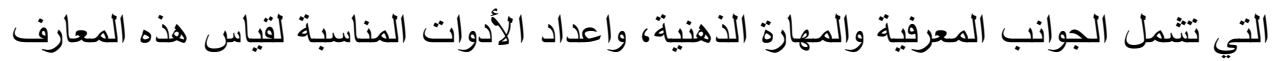

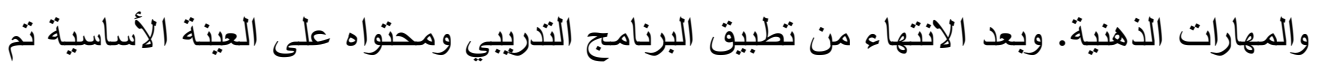

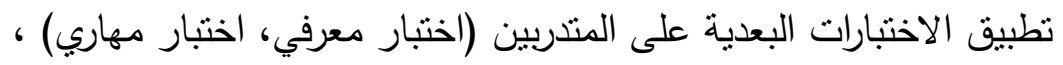
نتائج البحث الأن

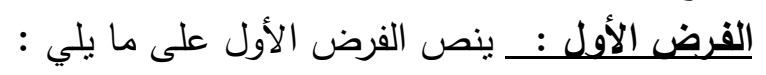

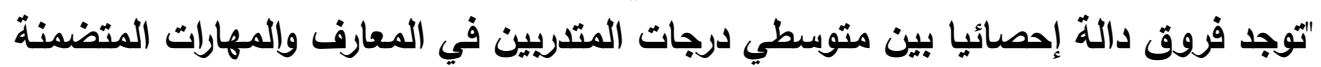

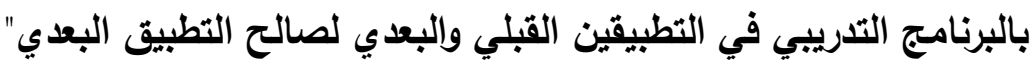
وللتحقق من هذا الفرض تم تطبيق اختبار "ت" والجدول التالي يوضح فئح ذللك: جدول (؟r) دلالة الفروق بين منوسط درجات المتدربين قبل وبعد نطبيق البرنامج التدريبي

\begin{tabular}{|c|c|c|c|c|c|c|}
\hline واتجاهـى الدلالة & قيمة ت & "درجات & عدينة أفراد & الانحراف & لالحسابي "م" & الفاعلية \\
\hline$\ldots 1$ & \multirow{2}{*}{$\begin{array}{l}r v . v 1 \\
r\end{array}$} & \multirow[b]{2}{*}{19} & \multirow[b]{2}{*}{$r}$. & r.TrV & 11.190 & القبلي \\
\hline لالبعدي & & & & 0.111 & Tr.YI. & البعدي \\
\hline
\end{tabular}

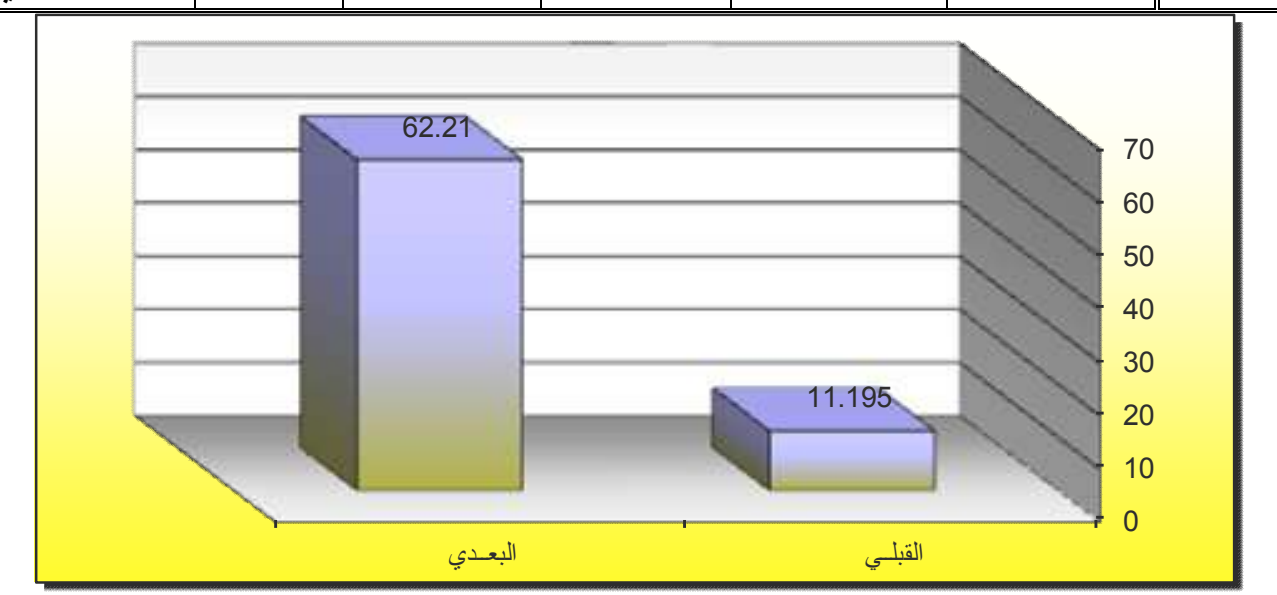

شكل (r) يوضح الفروق بين متوسط درجات المندربين قبل وبعد نطبيق البرنامج التدريبي 
يتضح من الجدول (r) والثكل (Y) : أن قيمة "ت" تساوي "rV.VIT" وهي قيمة ذات دلالة

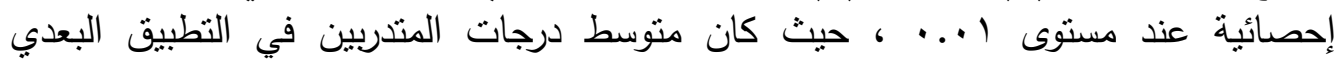

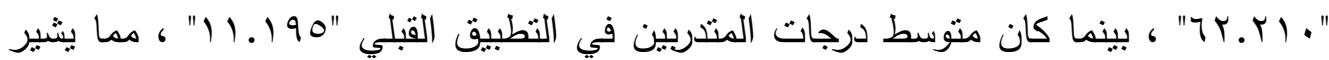

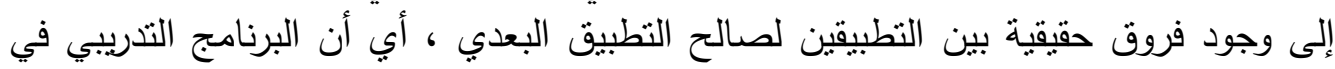

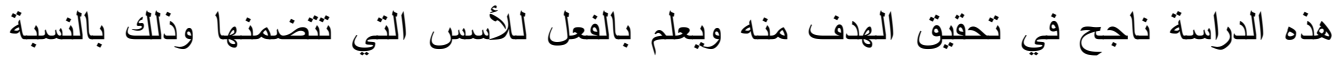
للمعارف والمهارات.

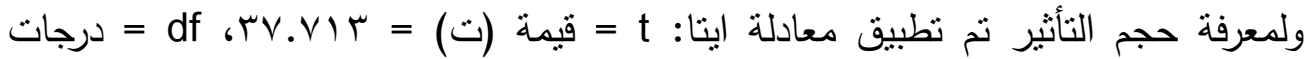

$$
\begin{aligned}
& \text { الحرية = } 19 \\
& n^{2}=\frac{t^{2}}{t^{2}+d f}=0.987 \\
& \text { وبحساب حجم التأثير وجد إن } \\
& d=\frac{\sqrt{n^{2}}}{\sqrt{1-n^{2}}}=17,37
\end{aligned}
$$

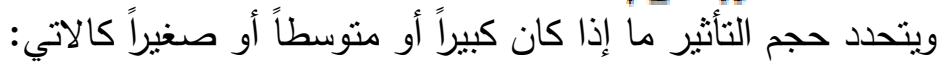

(r)

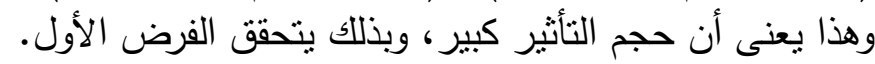

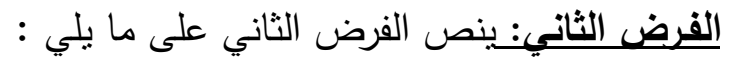

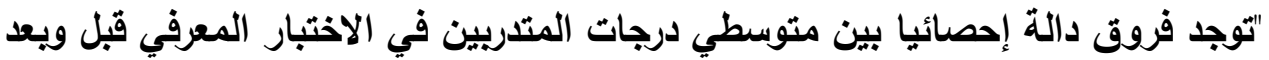

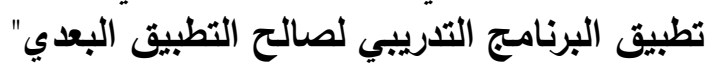

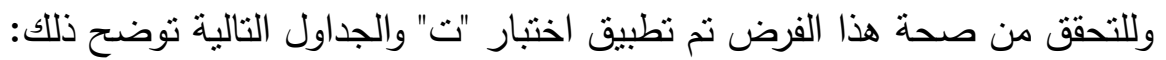

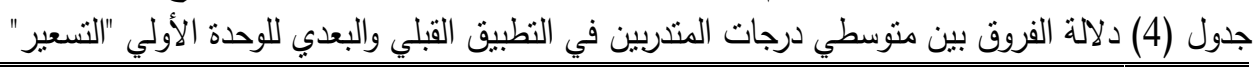

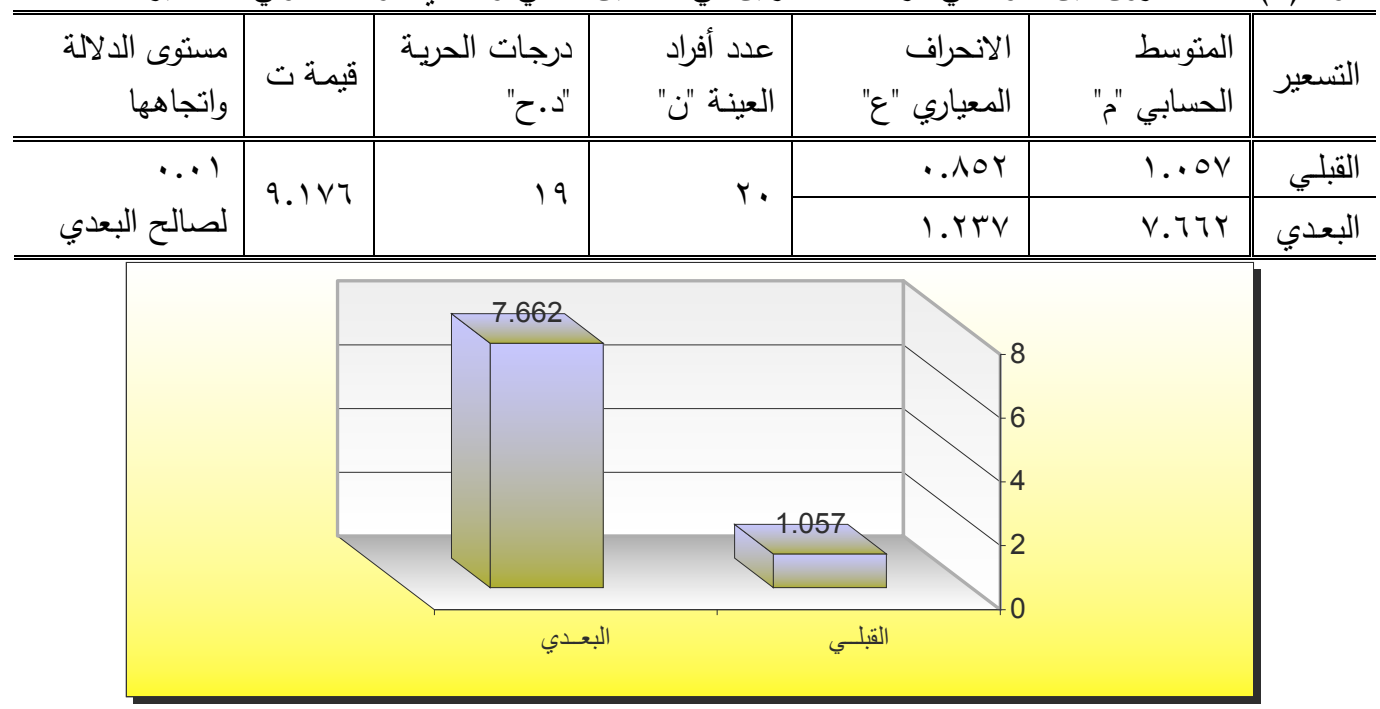

شكل (r) يوضح الفروق بين منوسطي درجات المندربين في التطبيق القبلي والبعدي للوحدة الأولي "التسعير" دئ المنين 


\section{يتضح من الجدول (ع) وإلشكل (r) :}

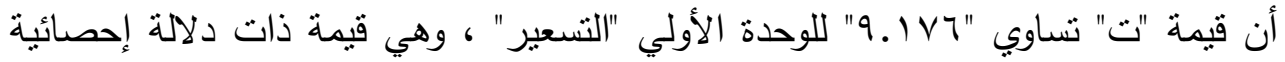

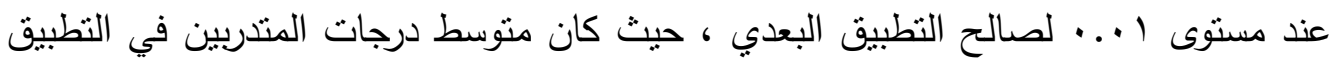

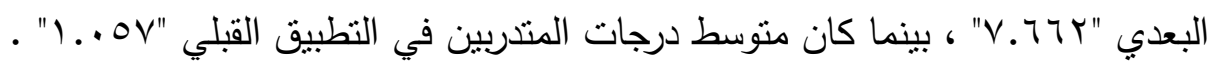

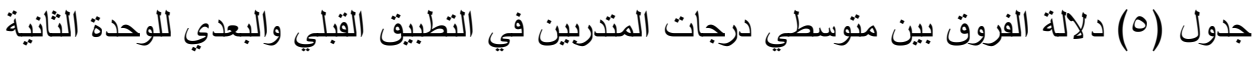

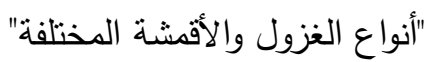

\begin{tabular}{|c|c|c|c|c|c|c|}
\hline ماتلالة & قيمة ت & "درجات & العينة "ند أفراد & الالمعياري "ع" & الحسابي "م" الحتوسط & الأنواع الغزولة \\
\hline$\ldots 1$ & & & &.$r r$ & $\therefore V \leqslant 7$ & القبلي \\
\hline لصالح & $\Lambda .+\lambda)$ & 19 & r. & 1.人ז & $7.99 \varepsilon$ & البعدي \\
\hline
\end{tabular}

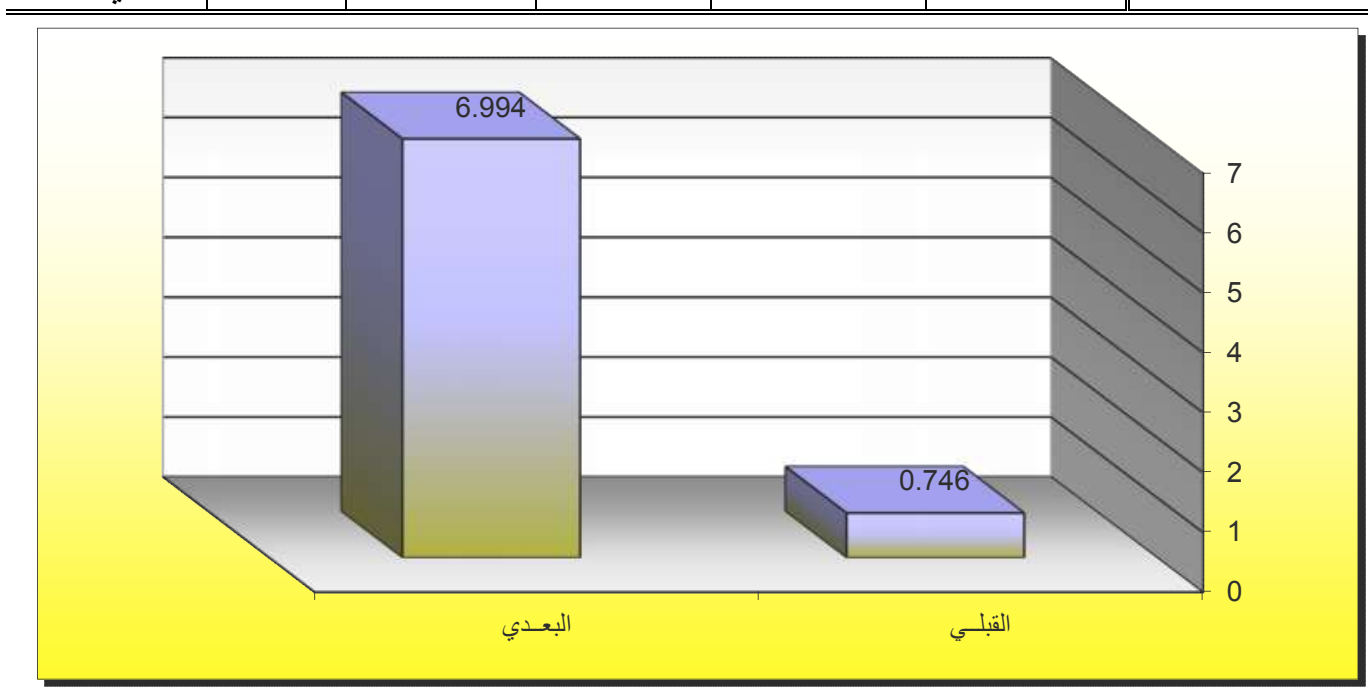

شكل (ع) يوضح الفروق بين منوسطي درجات المندربين في التطبيق القبلي والبعدي للوحدة الثانية

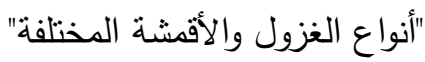

\section{يتضح من الجدول (0) والثكل (ع) :}

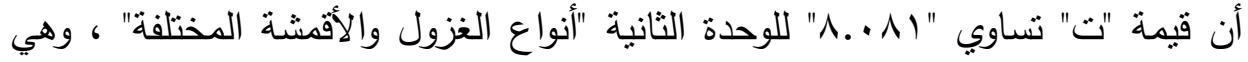

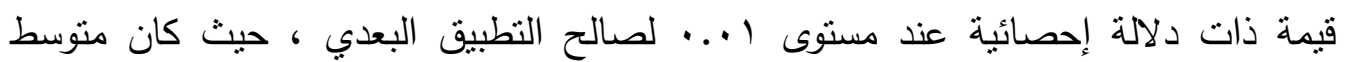

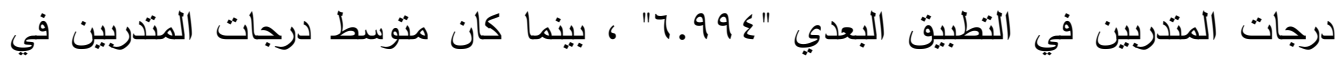

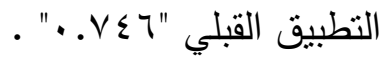
جدول (آ) دلالة الفروق بين متوسطي درجات المتدربين في التطبيق القبلي والبعدي للوحدة الثالثة

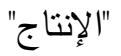




\begin{tabular}{|c|c|c|c|c|c|c|}
\hline | مستوى & قيمة ت & درجات "درية & العينة "ن" & الالنحراف & الحسابي "م" & الإنتاج \\
\hline$\ldots 1$ & \multirow[b]{2}{*}{0.009} & \multirow[b]{2}{*}{19} & \multirow[b]{2}{*}{$r}$. &.$I T V$ & .001 & القبلي \\
\hline لصالح & & & & $1 \ldots 9$ & 纟.rqV & البعدي \\
\hline
\end{tabular}

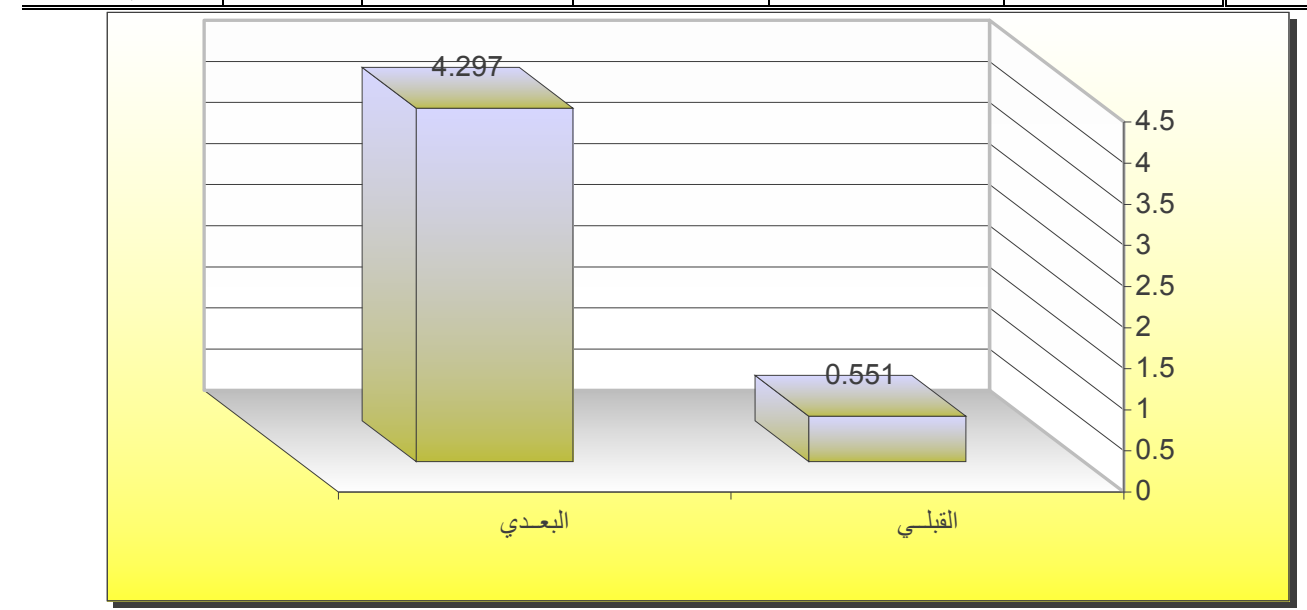

شكل (0) يوضح الفروق بين متوسطي درجات المندربين في النطبيق القبلي والبعدي

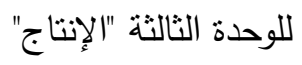

\section{يتضح من الجدول (7) والشكل (0) :}

أن قيمة "ت" تساوي "0.009" للوحدة الثالثة "الإنتاج"، وهي قيمة ذات دلالة إحصائية عند مستوى 1 ... لصالح التطبيق البعدي، حيث كان متوسط درجات المتدربين في التطبيق البعدي

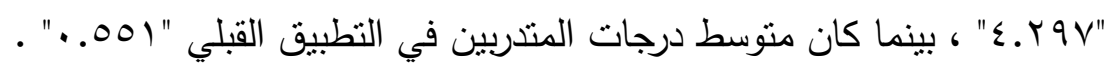
جدول (V) دلالة الفروق بين منوسطي درجات المتدربين في النطبيق القبلي والبعدي للوحدة الرابعة

\begin{tabular}{|c|c|c|c|c|c|c|}
\hline \multicolumn{7}{|c|}{ "القيمة المضافة" } \\
\hline واتجاهوى الدلالة & قيمة ت & 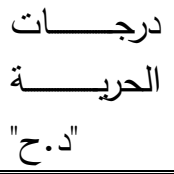 & عدلد أفراد & الانحراف & الحسابي "م" & المضافة \\
\hline$\cdots 1$ & \multirow[b]{2}{*}{$\Lambda . \vee Y q$} & \multirow[b]{2}{*}{19} & \multirow[b]{2}{*}{ r. } & .910 & $r . . r I$ & القبلي \\
\hline لصالح & & & & r...1A & 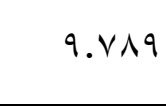 & عدي \\
\hline
\end{tabular}




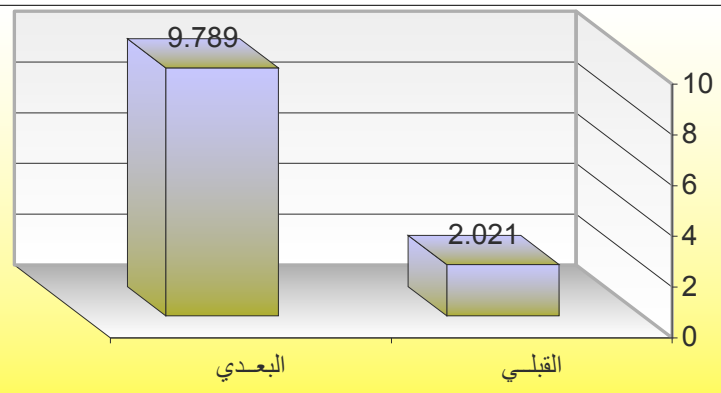

شكل (7) يوضح الفروق بين متوسطي درجات المتدربين في التطبيق القبلي والبعدي للوحدة

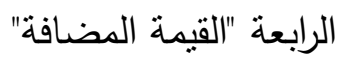

يتضح من الجدول (V) والثكل (T): (T)

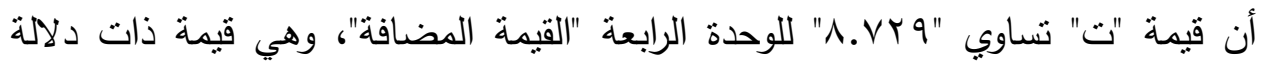

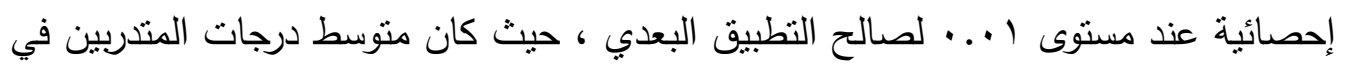

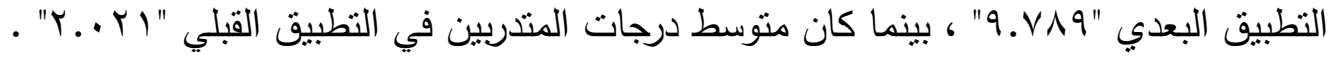
جدول (^) دلالة الفروق بين متوسطي درجات المتدربين في التطبيق القبلي والبعدي للوحدة الخامسة التونة

\begin{tabular}{|c|c|c|c|c|c|c|}
\hline \multicolumn{7}{|c|}{ "الثحن والنسليم" } \\
\hline مستوى الدلالة & قيمة & درجات & عدد أفراد & الانحراف & المتوسط & الثحن \\
\hline واتجاهها & ت & "د.ح"ح" & العينة "ن" & المعياري "ع" & الحسابي "م" & والتسليم \\
\hline$\cdots 1$ & $\{.10$ & \multirow{2}{*}{19} & \multirow{2}{*}{$r}$. & $\cdot .1 \cdot r$ &..$\leqslant \leqslant 1$ & القبلي \\
\hline لصالح البعدي & 9 & & & 1.01. & r.99V & البعدي \\
\hline
\end{tabular}

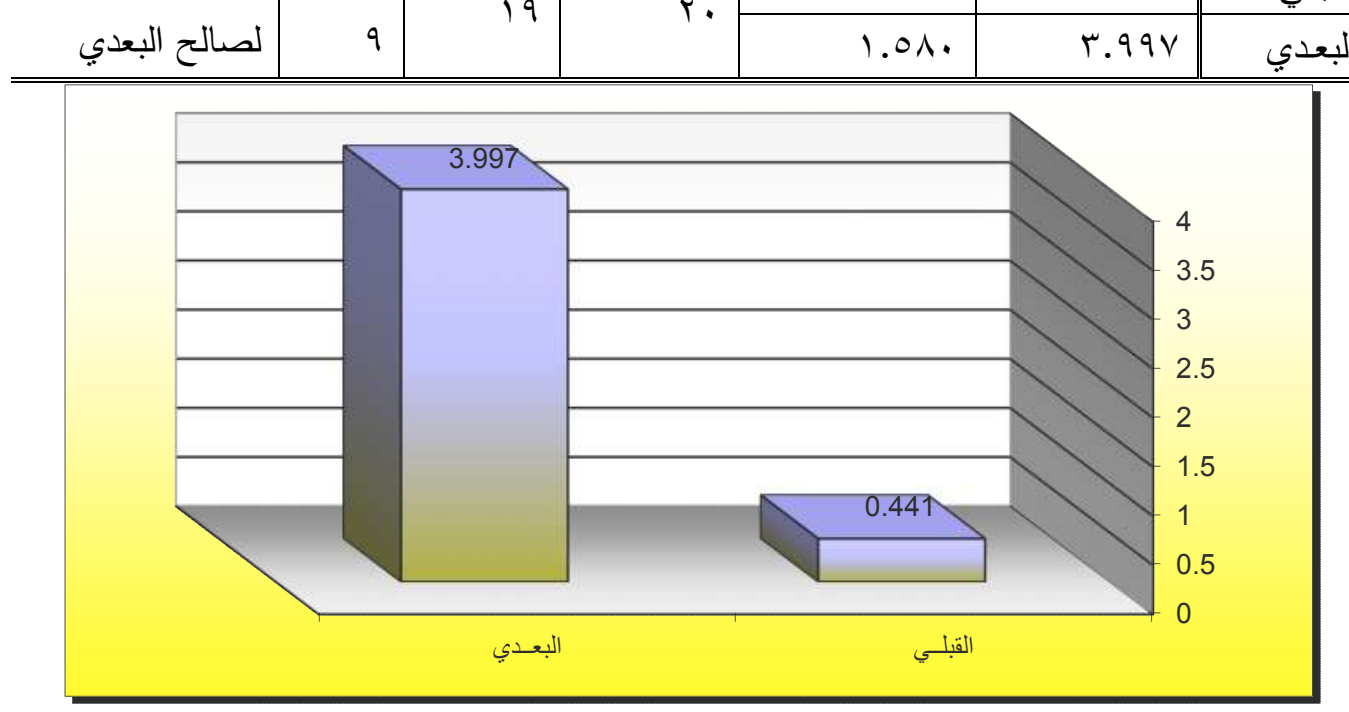

شكل (V) يوضح الفروق بين متوسطي درجات المندربين في التطبيق القبلي والبعدي للوحدة الخامسة "الثحن والتسليم" في في الثنات 


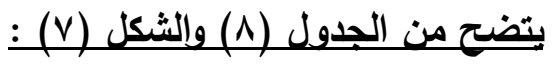

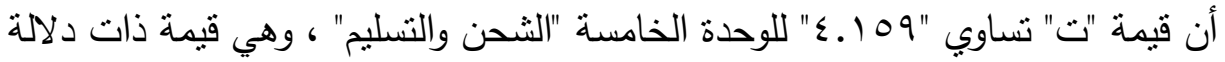

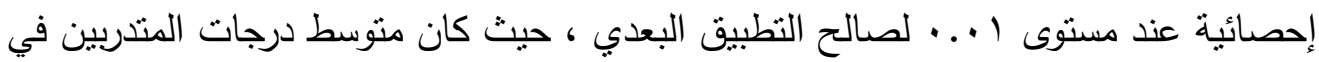

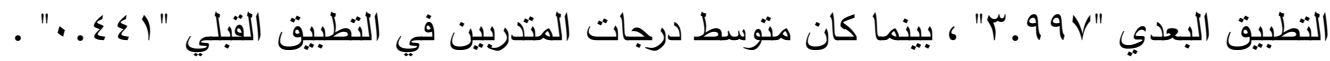

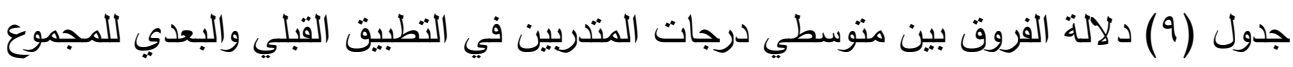

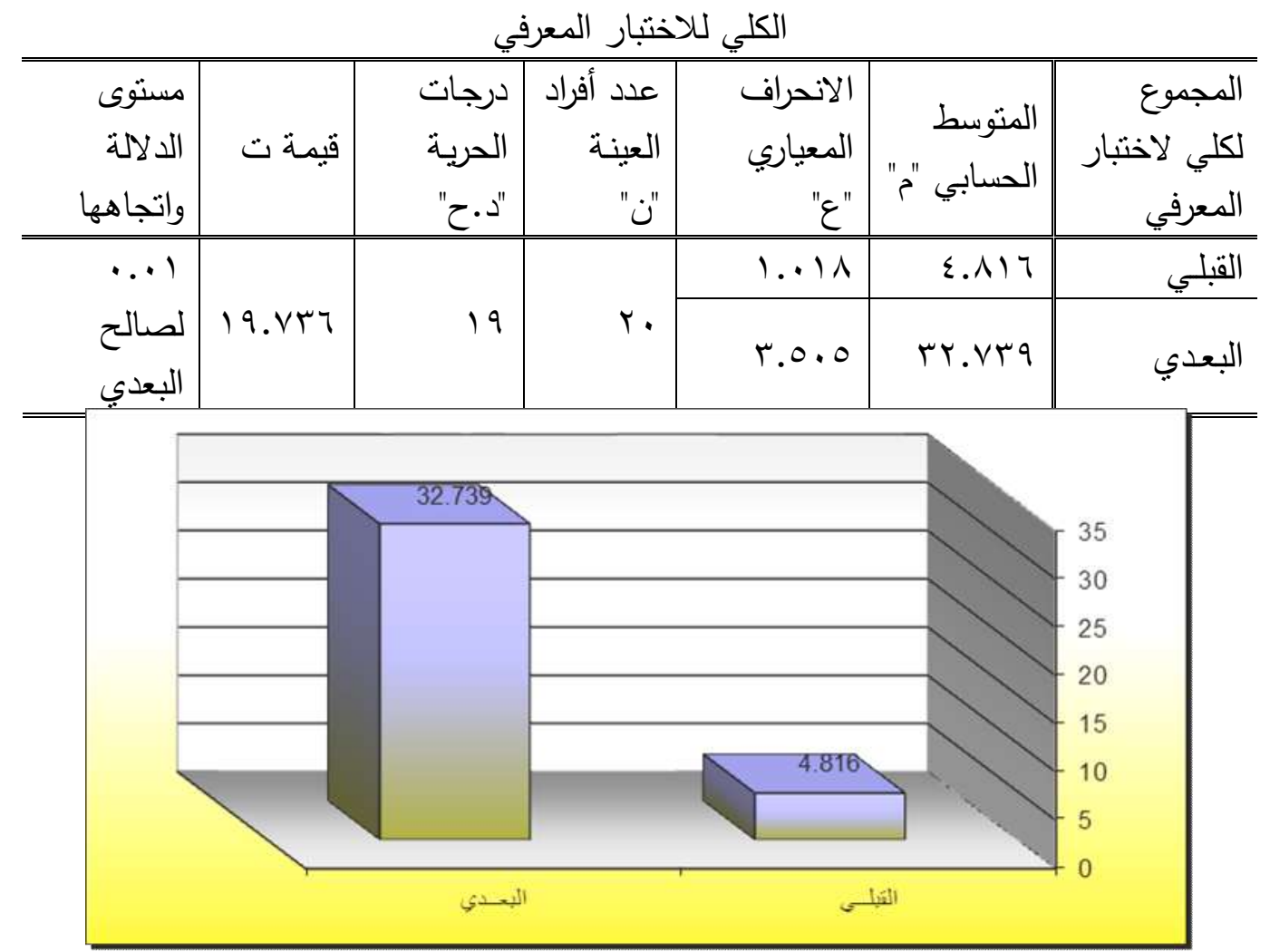

شكل (^) يوضح الفروق بين منوسطي درجات المتدربين في التطبيق القبلي والبعدي للمجموع الكلي للاختبار المعرفي دات التصني

يتضح من الجدول (9) والشكل (^) :

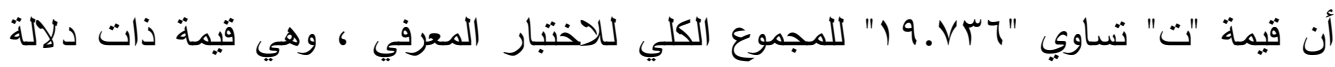

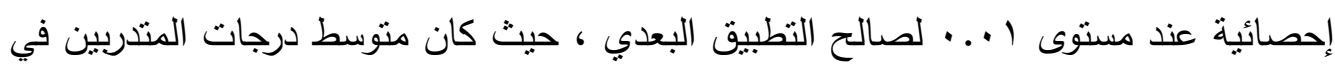

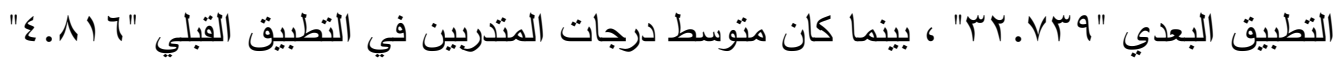

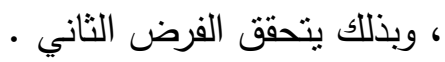

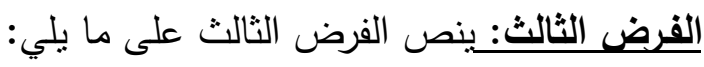
"توجد فروق دالة إحصائيا بين متوسطي درجات المتدربين في الاختبار المهاري قبل ويعد تطبيق البرنامج التريبي لصالح التطبيق البعدي" دئي 
وللتحقق من صحة هذا الفرض تم تطبيق اختبار "ت" والجداول التالية نوضح ذللك: جدول (• (1) دلالة الفروق بين متوسطي درجات المتدربين في التطبيق القبلي والبعدي للوحدة الأولي

\begin{tabular}{|c|c|c|c|c|c|c|}
\hline \multicolumn{7}{|c|}{ "التسعير" } \\
\hline واتجاهنوى الدلالة & قيمة ت & درجات "الحريـة "د.ح" & العينة "ند أفراد & الانعراف & الحسابي "م" الحسط & التسعير \\
\hline$\cdots 1$ & \multirow{2}{*}{. .91} & \multirow{2}{*}{19} & \multirow{2}{*}{$r}$. & . &.$\wedge \wedge 1$ & القبلي \\
\hline لصالح البعدي & & & & 1.119 & $r .079$ & البعدي \\
\hline
\end{tabular}

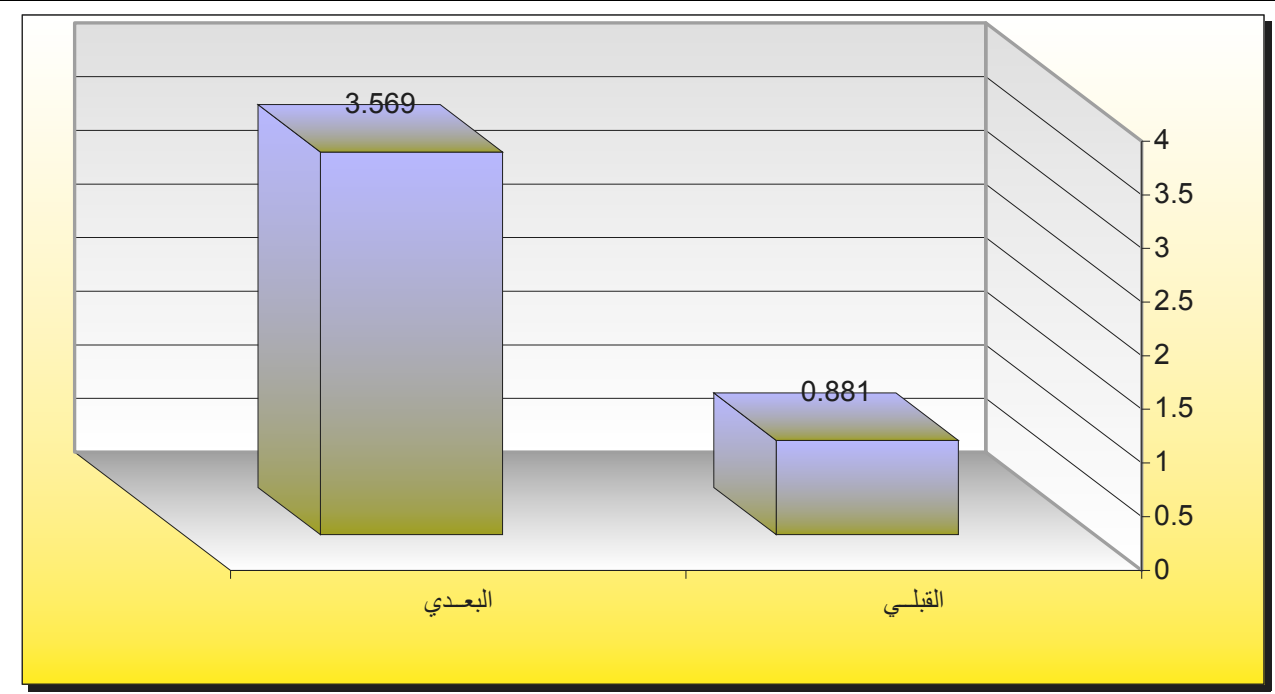

شكل (9) يوضح الفروق بين منوسطي درجات المتدبين في التطبيق القبلي والبعدي للوحدة الأولي "التسعير"

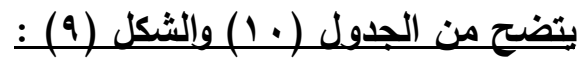

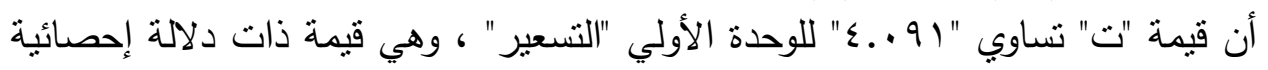

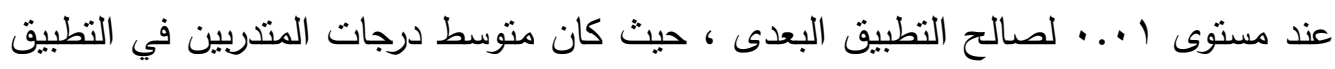

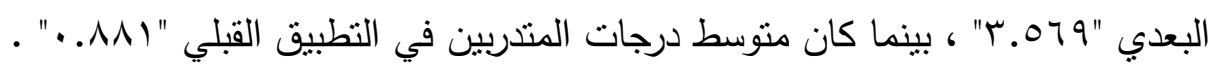

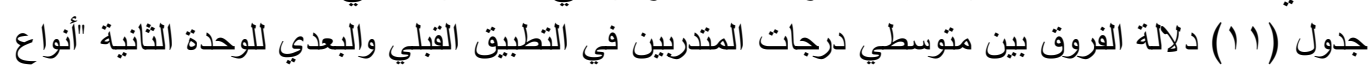

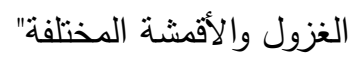

\begin{tabular}{|c|c|c|c|c|c|c|}
\hline ماتدلالة & قيمة ت & دالحرية"د. ح"ح & العينة "ند أفراد & الانحراف & الحسابي "م" & أنواع الغزولة المختلفة \\
\hline$\cdots 1$ & \multirow[b]{2}{*}{$0 . r \vee \wedge$} & \multirow[b]{2}{*}{19} & \multirow[b]{2}{*}{$r}$. & צד & .094 & القبلي \\
\hline لصالح & & & & $1 . \leqslant 07$ & 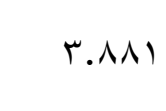 & البعدي \\
\hline
\end{tabular}




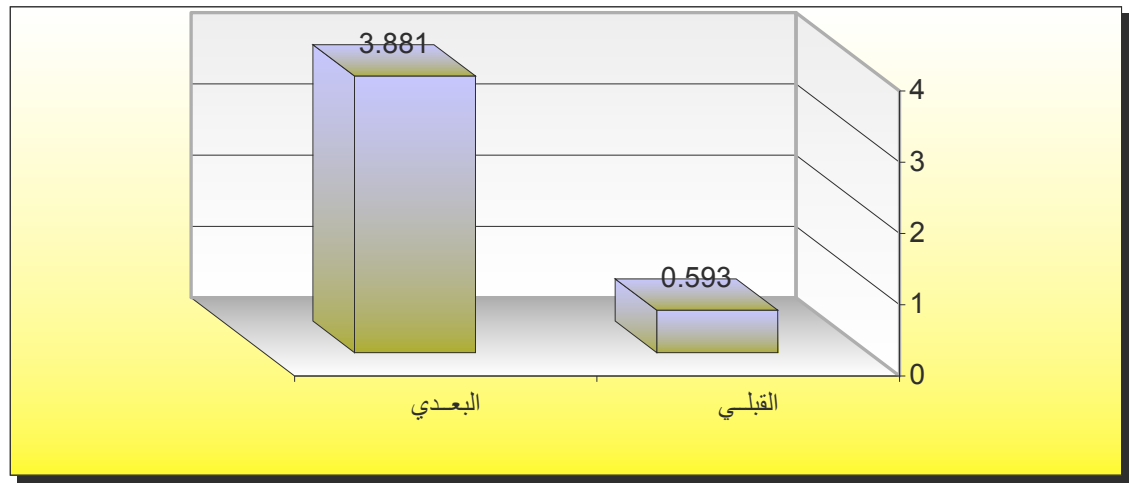

شكل (• ( ) يوضح الفروق بين متوسطي درجات المندربين في التطبيق القبلي والبعدي للوحدة الثانية

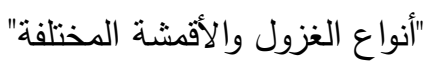

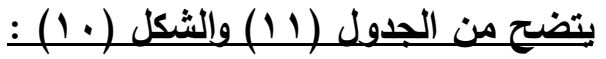

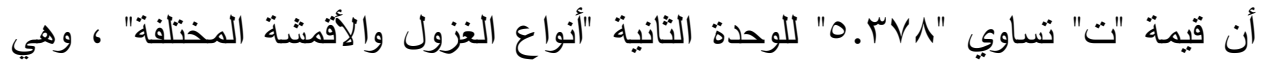

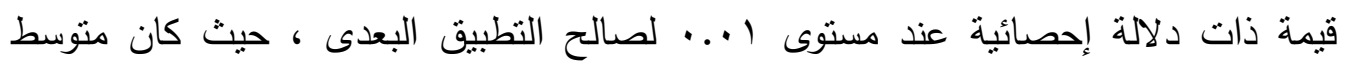

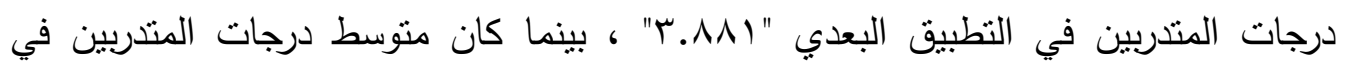

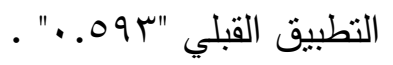

جدول (r ا ( دلالة الفروق بين متوسطي درجات المندربين في النطبيق القبلي والبعدي للوحدة الثالثة

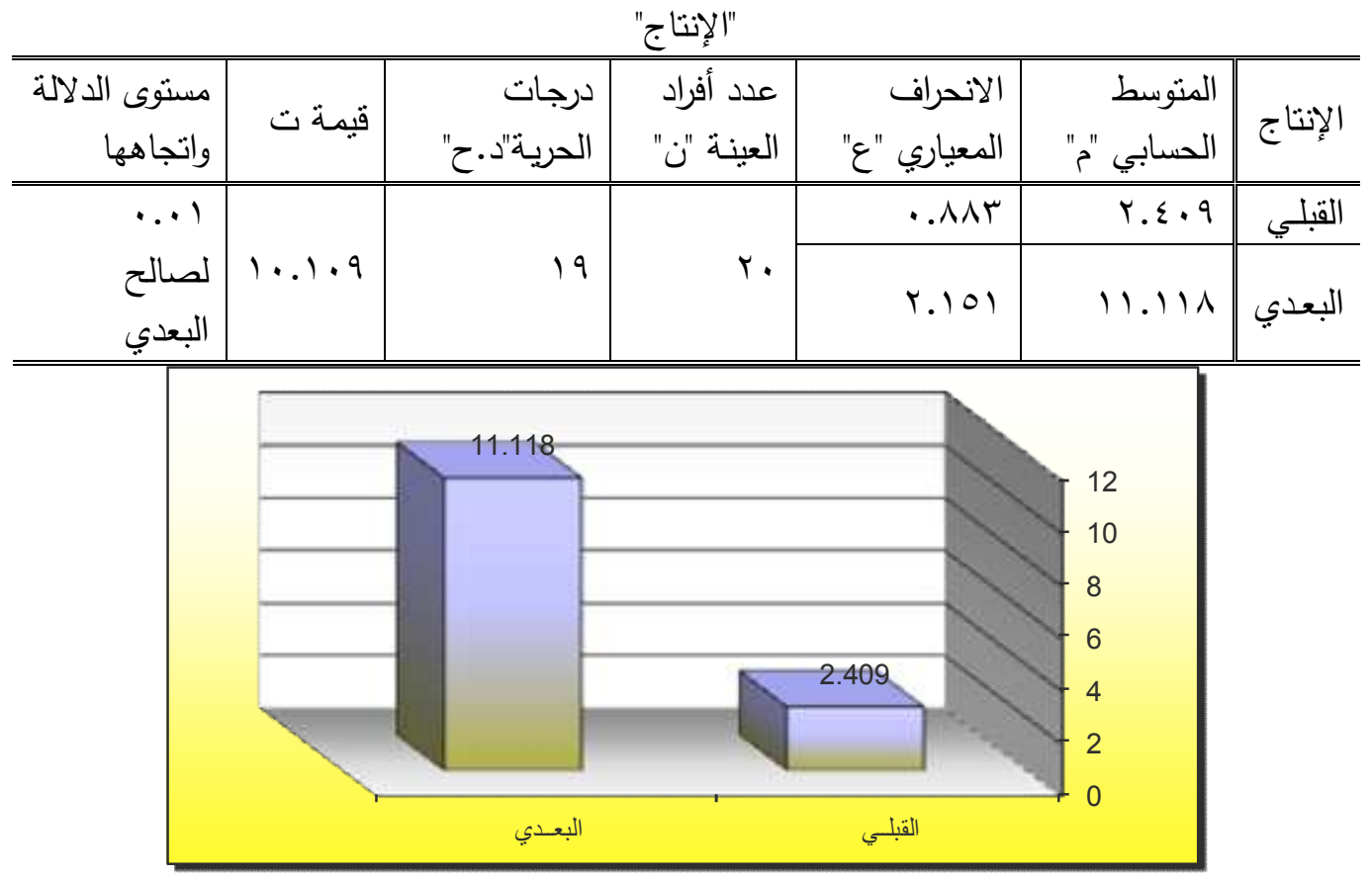

شكل (1) يوضح الفروق بين متوسطي درجات المتدربين في التطبيق القبلي والبعدي للوحدة

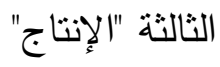




\section{يتضح من الجدول (r I I) والثكل (11) : (11)}

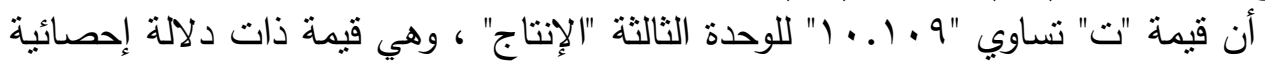

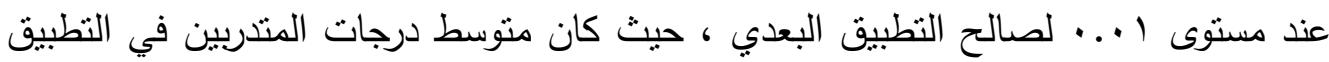

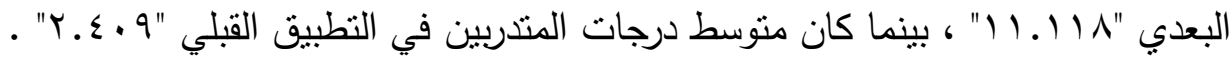

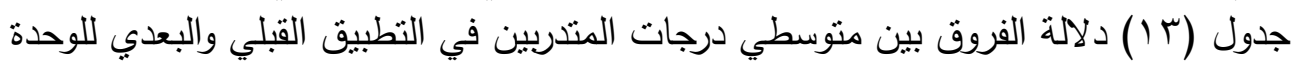

الرابعة "القيمة المضافة" المنانين في

\begin{tabular}{|c|c|c|c|c|c|c|}
\hline $\begin{array}{r}\text { مستوى الدلالة } \\
\text { واتجاهها }\end{array}$ & قيمة ت & 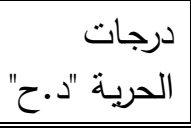 & عدد أفراد & 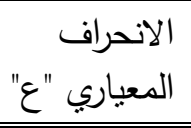 & الحستوسط "ابي "م" & القيمة \\
\hline$\ldots 1$ & \multirow[b]{2}{*}{ V.rYq } & \multirow[b]{2}{*}{19} & \multirow[b]{2}{*}{$r}$. & $\because \vee V 4$. & $1.77 \mathrm{~V}$ & القبلي \\
\hline لصالح & & & & אזr. & $V .197$ & البعدي \\
\hline
\end{tabular}

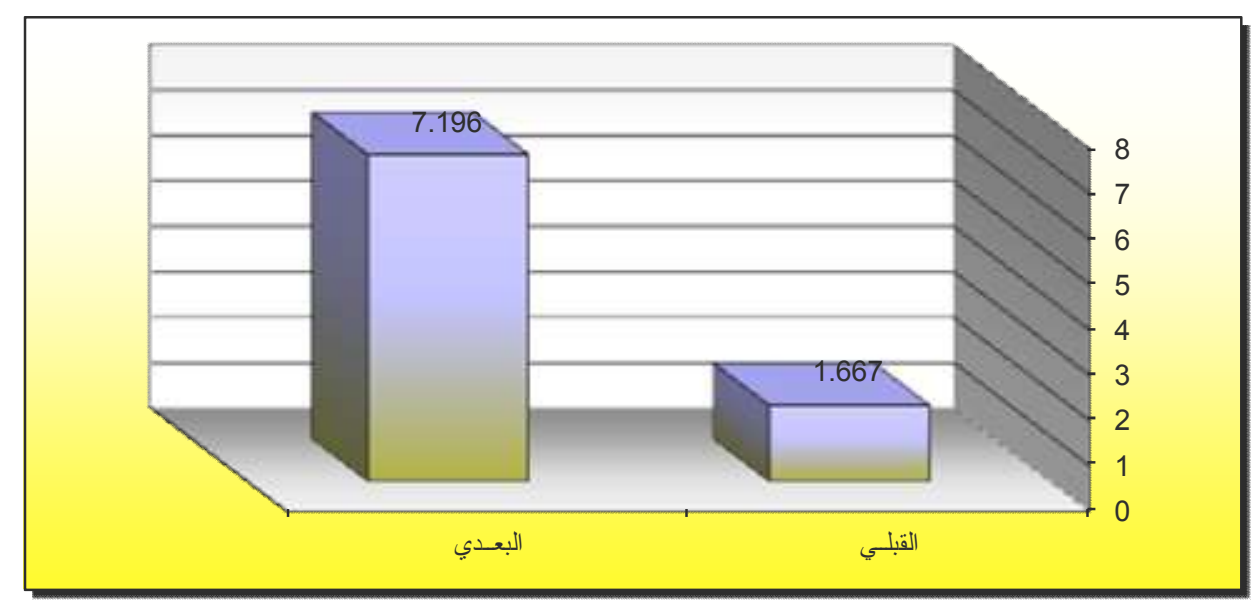

شكل (r ( ) يوضح الفروق بين متوسطي درجات المتدربين في النطبيق القبلي والبعدي للوحدة

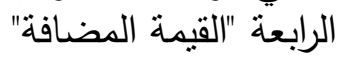

يتضح من الجدول (r) والثكل (I I I):

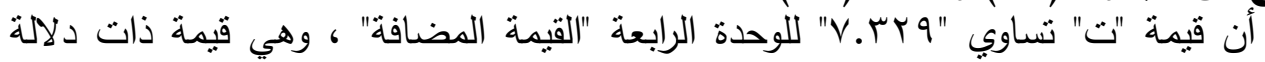

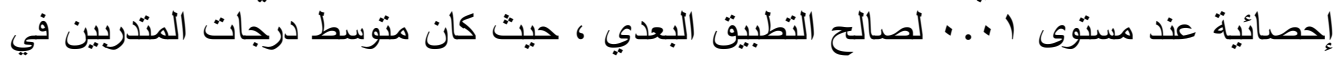

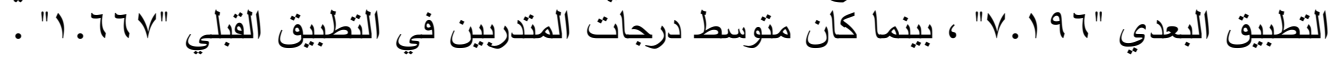

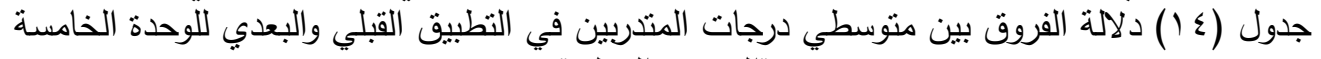

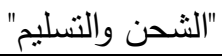

\begin{tabular}{|c|c|c|c|c|c|c|}
\hline واتجاهـا الدلالة & قيمـة ت & دالحرية "د.ح" & عدد أفراد & الانحراف "عياري "ع" & الحسابي "إس " المتوسط & والتسليم \\
\hline \multirow{2}{*}{ لصُالح البعدي } & \multirow{2}{*}{$0 . \ldots 0$} & \multirow{2}{*}{19} & \multirow{2}{*}{$r$. } & +. $\varepsilon \cdot 1$ & . . Arq & القبلي \\
\hline & & & & 1.77. & $r . V \cdot V$ & البعدي \\
\hline
\end{tabular}




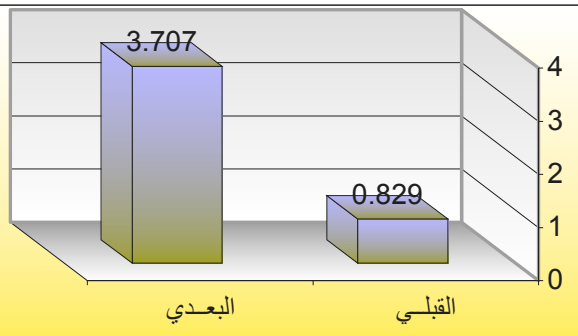

شكل (r ا ) يوضح الفروق بين متوسطي درجات المتدربين في التطبيق القبلي والبعدي للوحدة

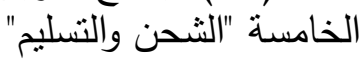

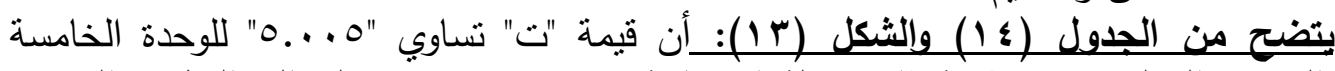

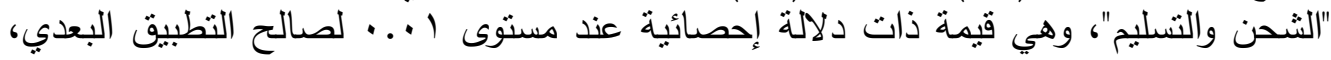

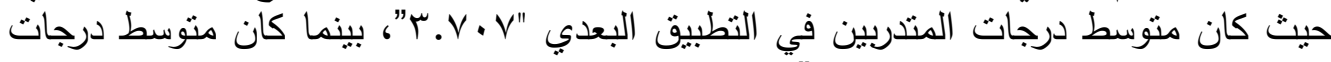

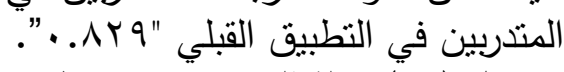
جدول (10) دلالة الفروق بين منوسطي درجات المندربين في التطبيق القبلي والبعدي للمجموع الكلي

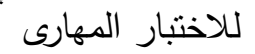

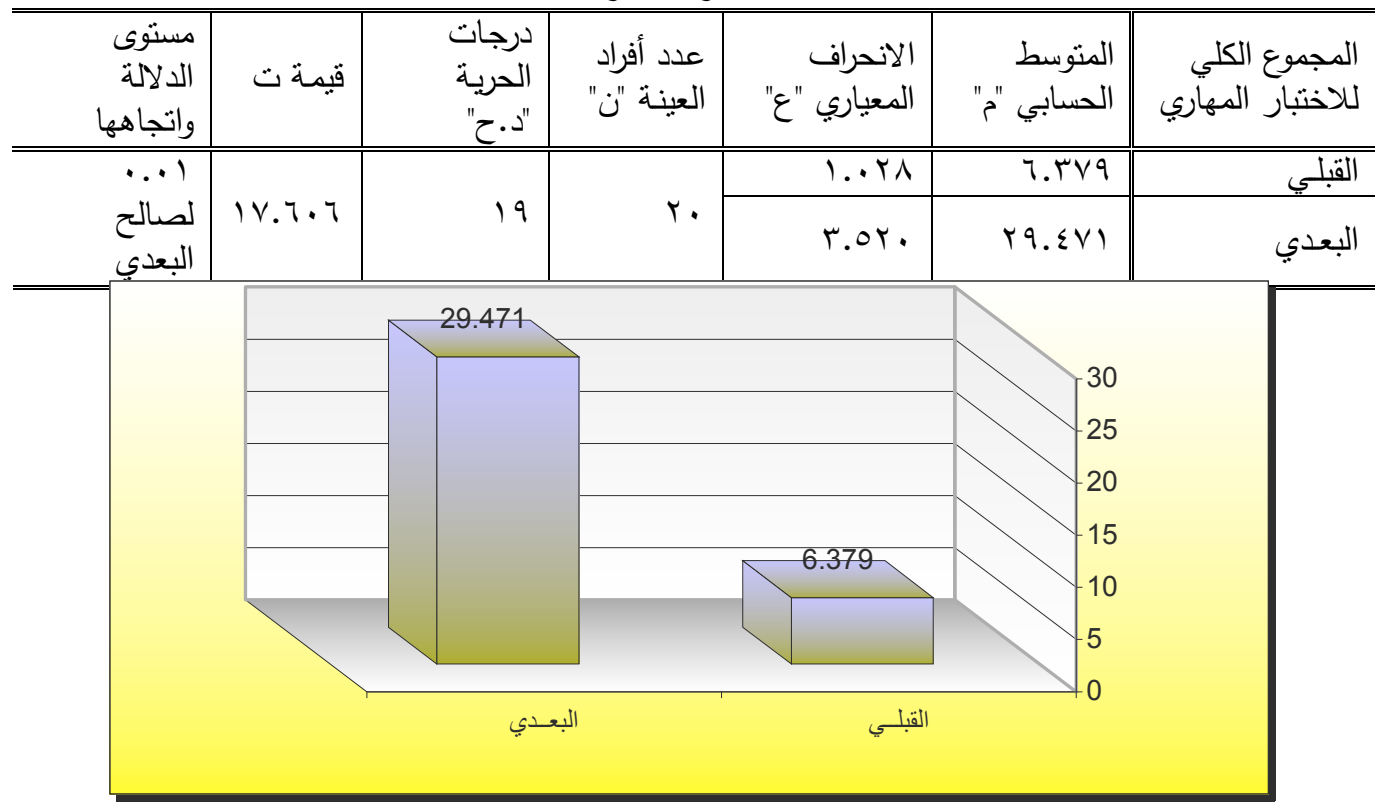

شكل (ء () يوضح الفروق بين متوسطي درجات المندربين في التطبيق القبلي والبعدي للمجموع الكلي لـاختبار المهارى

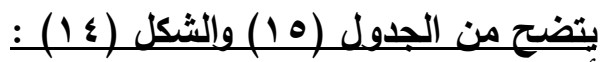

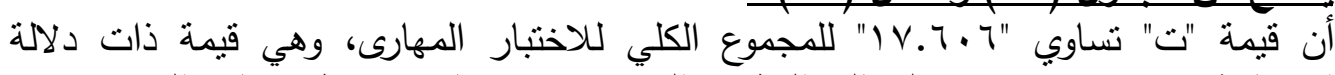

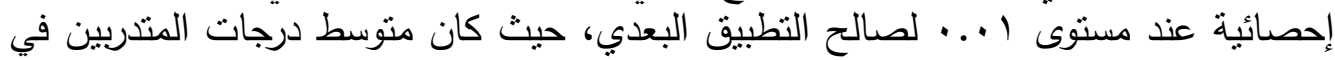

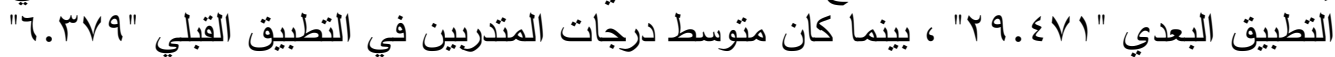
، وبذلك يتحقق الفرض الثالث " ل 


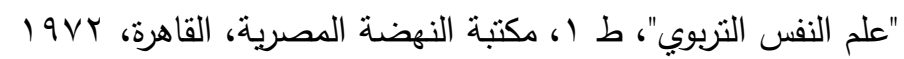
"تكنولوجيا القص في صناعة الملابس الجاهزة وأثرها على جودة المنتج"،

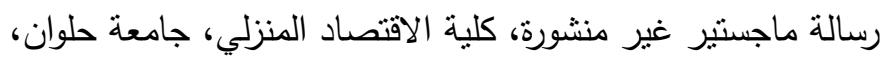
1999

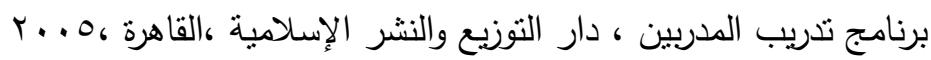

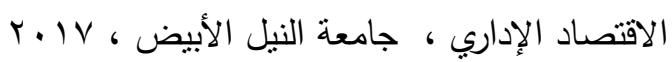

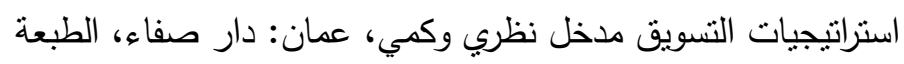

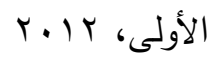

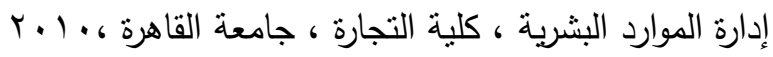
التسويق الصيدلاني، دار اليازوري العلمية للنشر والتوزيع، الطبعة العربية،

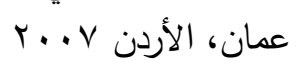

سياسات التسعير وخصومات البيع، برنامج مهارات البيع والتسويق، كلية

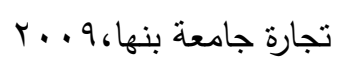
"تسويق الخدمات الصحية “، دار اليازوري، الاردن،ه . . ب

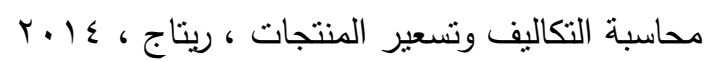
"التدريب الإداري المعاصر"، الطبعة الأولى، عمان الأردن، دار المسيرة

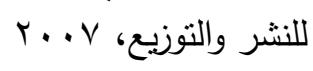

دراسة بعض المشاكل التسويقية للملابس الجاهزة النسائية المصنعة في

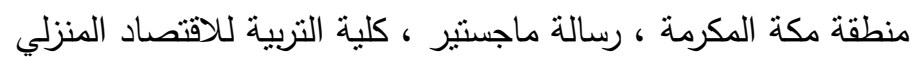

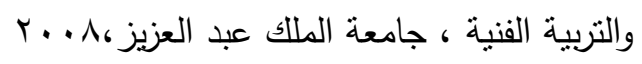
التسويق الصيدلاني حالة مجمع (صبدال) ، جامعة دالي إبراهيم - الجزائر r. 1. 6

"سيكولوجية التدريب وتتمية الموارد البشرية"، دار الفكر العربي، القاهرة ، 1. . ب المشروعات الصغيرة الفرص والتحديات ، مركز تطوير الدراسات العليا

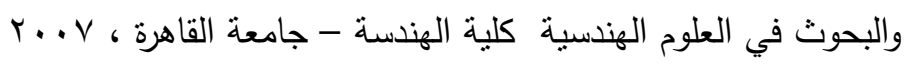
"إدارة الموارد البشرية من الناحية العلمية والعملية"، الادارة الجامعية،

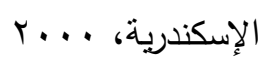

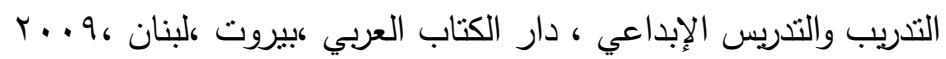

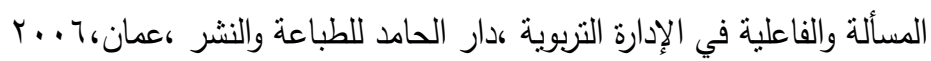

$$
\begin{aligned}
& \text { قائمة المراجع } \\
& \text { احمد زكي صالح } \\
& \text { اسامة محمد حسين } \\
& \text { أبو هثيمة } \\
& \text { اكرم رضا } \\
& \text { الثاذلي عيسى حمد رضد } \\
& \text { النسور ، إياد عبد } \\
& \text { الفتاح }
\end{aligned}
$$

امل عبدالرحمن السيد

بثير العلاق

بيومي محمد عماره

ثامر البكري

جعفر القواس البري

حسن أحمد الطعانى

داليا عبدالكريم أحمد قنديل

دحمان ليندة ، العمري العربي رأفت السيد عبد الفتاح

سيد كاسب ،جمال كمال الدين

صلاح الدين محمد

طارق سويدان عالية خلف: 
علم النفس في المجال التربوي، الطبعة الثانية، دار المعرفة الجامعية،

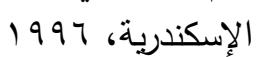

سياسات النسعير ، اقتصاد إداري، كلية الاقتصاد والإدارة، جامعة الملك

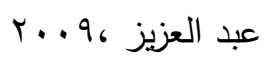

تحديد الاحتياجات التدريبية لضمان فاعلية البرامج التدريبية"، ط ل1 1 دار

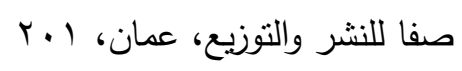

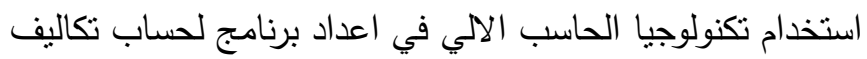

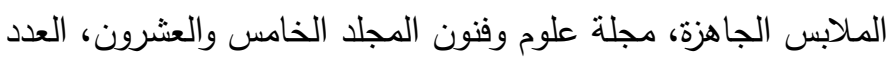

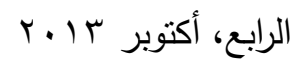

علم النفس التربوي، الطبعة الثالثة، مكتبة الانجلو، القاهرة، .. r. الاتجاهات في المناهج و طرق التدريس، طس ، عالم الكتب ، القاهرة r...

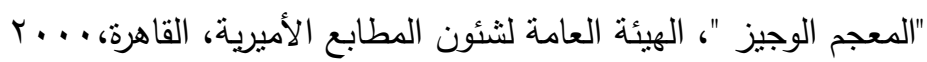

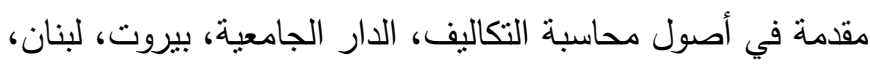
199.

إدارة الموارد البشرية في مواقع العمل - الأسس العلمية والممارسات

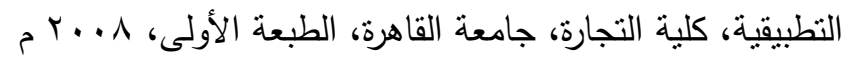
تصميم وإعداد المناهج التدريبية، مركز تطوير الأداء والتتمية للنشر

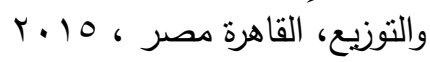
الاشتراف التربوي الحديث، مكتبة الاسراء، الكويت، ا... "مراحل العملية التدريبية- تخطيط ونتائج وتقوين البرامج التدريبية"، الطبعة

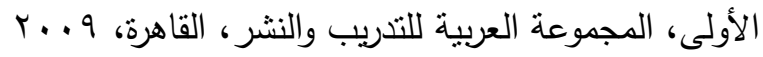

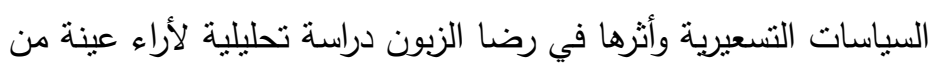

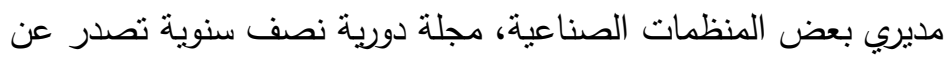

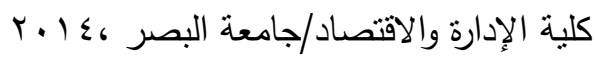

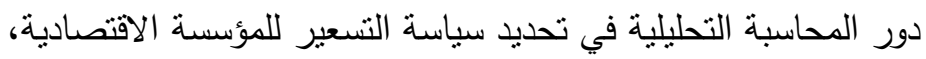

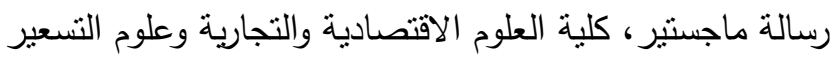

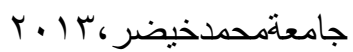

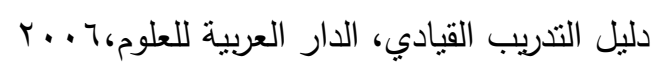

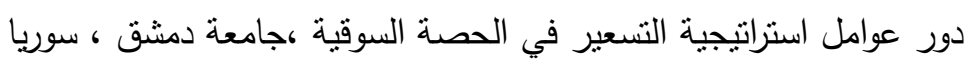

عبد الرحمن عيسوي عبلة عبد الحميد بخاري عصام عطا اله حسين عواطف بهيج إبراهيم، جيهان محمود عبد إيدان الحمبد فؤاد أبو حطب، أمال صادق كوثر حسين كوجك مجمع اللغة العربية محمد الفيومي محمد

$$
\text { محمد أيمن عبد محمد عدم هلد الغني }
$$

نضال بدر شيت هادفي خالد هشام الطالب وسام أبوامين 